\title{
Production and Technology of Iron and Steel in Japan during 2005
}

\author{
Hiroshi KAGECHIKA
}

Chief of the Technical Society, the Iron and Steel Institute of Japan, Kanda-Tsukasacho, Chiyoda-ku, Tokyo 101-0048 Japan.

\section{Overview of Conditions in the Japanese Iron and Steel Industry}

General international conditions in 2005: Looking back on world events during 2005, in addition to a succession of terrorist bombings, this was a year when, as in the previous year, nature showed its violence in a great earthquake in northern Pakistan (Kashmir region) and hurricane in the southern United States. In particular, triggered by the damage to oil refining facilities in the southern U.S. caused by Hurricane Katrina, the price of oil briefly broke the \$70/barrel (WTI) barrier. Although a subsequent emergency release from the Strategic Petroleum Reserve temporarily brought oil prices back to the $\$ 50$ level, prices rose again to the $\$ 60$ level at year-end when a cold wave struck the northeastern U.S. These events had a major impact on the world economy.

Domestic conditions: In Japan, 2005 experienced an unbroken series of man-made problems, including a train accident at Amagasaki caused by the JR West rail line, serious health damage by asbestos, and widespread falsification of the seismic strength of condominiums and other buildings. At the end of the year, the government announced that the Japanese population has entered a decline for the first time since collection of statistics began; this was generally considered a historical turning point for Japan, a country that has continued to increase in population. In business, the trend of M\&A was extremely active during the year due to moves by IT-related companies. Amid these events, in August, the Minister for Economic and Financial Policy declared that the economy has now "emerged from the doldrums," and in November, the average share price on the Tokyo Stock Exchange recovered the $¥ 15000$ level for the first time in 5 years, reflecting the strength of expectations for an economic recovery. Thus, at least where the economy was concerned, there was no small number of bright spots.

International steel industry: Looking next at the international iron and steel industry, following a brief lull in the ongoing consolidation of the industry, a new round of activity was seen extending through the end of the year, as Arcelor and Thyssen made successive offers to purchase Dofasco, Mittal Steel announced the acquisition of three Stelco subsidiaries, India's Tata Group proposed to purchase Highveld Steel \& Vanadium (South Africa), and Mittal Steel South Africa also expressed an interest in the same company.

World iron and steel production has continued to show large increases since 2002 due to rapidly rising steel demand in China. Crude steel production achieved the 1 billion ton level for the first time in 2004 and set a new record in 2005, reaching 1.1 billion tons. A major factor in this was the fact that increases in Chinese production exceeded $25 \%$ in comparison with 2004 , offsetting moderate decreases in production from 2004 in the main producing countries, Japan, the U.S., and Europe (Fig. 1). China's crude steel production, which has shown astonishing growth since 2001, reached 350 million tons in 2005, increasing by 75 million tons from the previous year, and now accounts for more than $30 \%$ of total crude steel production worldwide. Steel demand also showed a firm trend through the year in Asia, the United States, and Europe, but as a result of concern about a deterioration in market conditions due to an oversupply situation in China, other countries began to reduce output. In July, the Chinese government announced a "Development Policy for the Iron and Steel Industry" which stresses a shift to high-grade products, consolidation of companies, and promotion of energy saving as main directions. World attention is now focused on the questions of when and in what form this policy will result in changes in China's crude steel production and technical development.

Japanese steel industry: In 2004, the Japanese steel industry devoted its full energies to increasing production. In contrast, in 2005 , the industry made a complete turnaround, adopting reduced production measures in response to the aforementioned increases in Chinese production. As a result, Japan's crude steel production in 2005 was 112.48 million tons, which was a 0.24 million ton decrease from the previous year, but was still the 4th highest output in Japan's history. In spite of this decrease, blast furnaces remained in full operation and pig iron production exceeded that in 2004 by 90000 tons, reaching 83.07 million tons. In crude steel production by furnace type, converter steel accounted for 83.63 million tons $(0.8 \%$ increase from 2004$)$ and electric arc furnace steel, 28.85 million tons $(3.1 \%$ decrease). As a result, the ratio of electric arc furnace steel fell to $25.6 \%$, or a decrease of $0.8 \%$. By steel type, ordinary steel accounted for 87.92 million tons (1.4\% decrease) and special steel, 24.56 million tons (4.1\% increase). The increase in special steels was conspicuous, and special steel production has now set new records for 4 consecutive years. Production of hot rolled steel products (total of ordinary steel and special steel) decreased by $1.9 \%$ from 2004, to 112.0 million tons, but was nevertheless on a high level, exceeding 100 million tons for the 3rd consecutive year and ranking 5th highest in history (Table 1). Domestic steel demand remained stable at a high level throughout the year in both the manufacturing and construction industries. Apparent domestic crude steel consumption was 83.10 million tons, for a 3.98 million ton increase in comparison with 


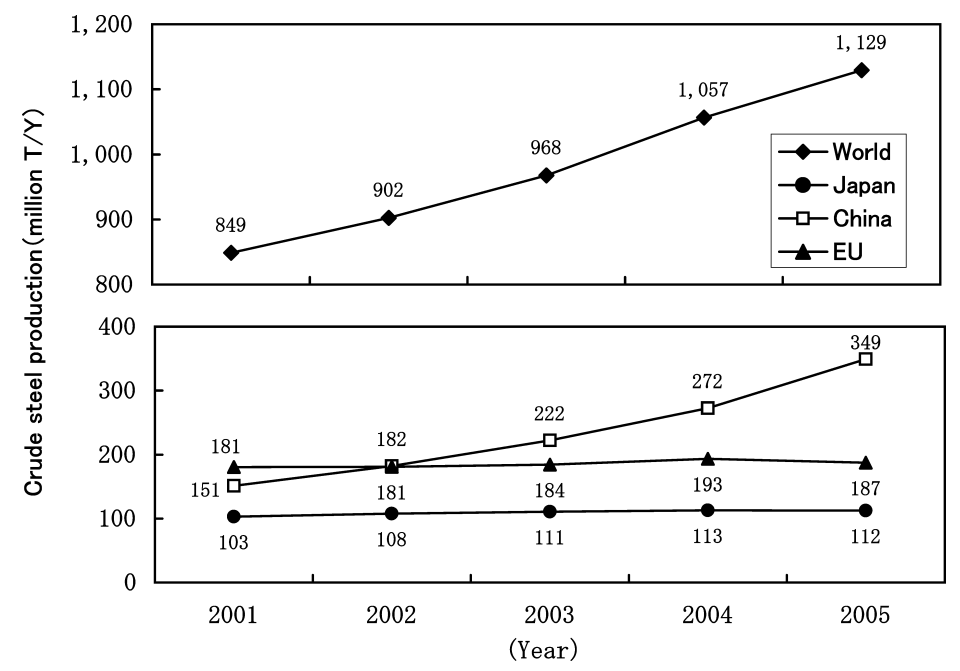

Fig. 1. Transition of crude steel production. Source: The Japan Iron and Steel Federation.

Table 1. Production of iron, steel and hot-rolled products.

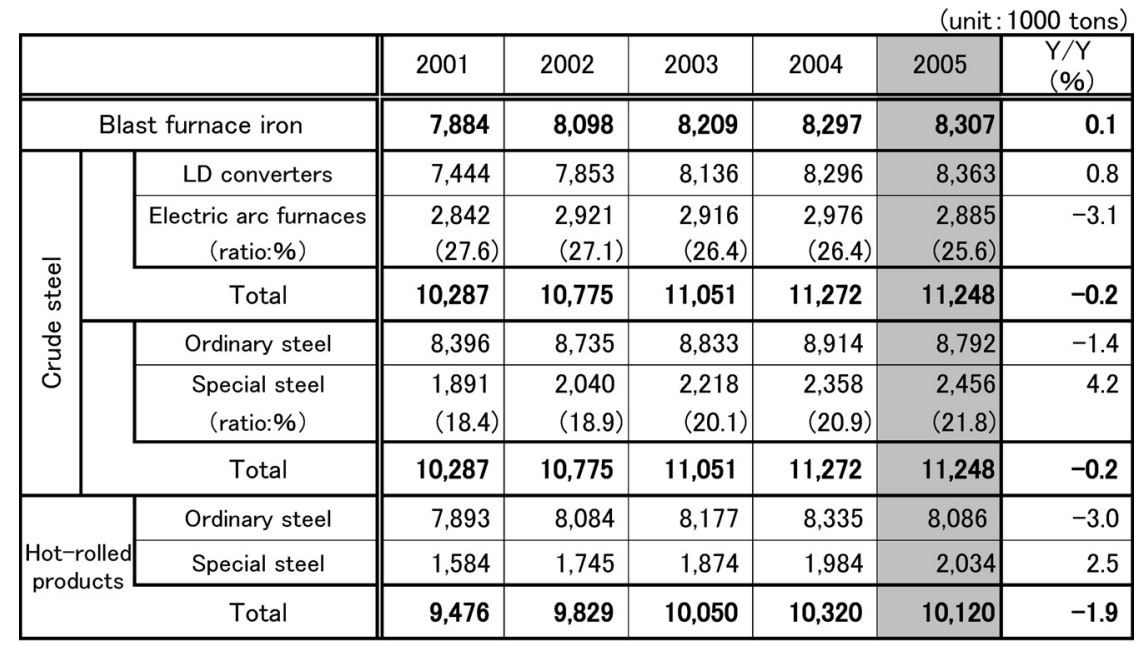

Source: The Japan Iron and Steel Federation

2004, while exports were 35.20 million tons, for a 3.12 million ton decrease.

Where raw material prices are concerned, large price increases affected both iron ore and coal, with iron ore prices rising by approximately $70 \%$ and coal more than doubling. In response to these trends, the steel industry began moves to secure new long-term agreements in 2004, aiming at stable procurement, and continued to conclude long-term agreements and strengthen its system of cooperation with suppliers in 2005. Domestic market prices for steel products showed a rising tendency until the spring of 2005, but entered a gradual decline in the second half of the year. On the other hand, the average export price has continued a steady rise which began from an initial $\$ 600 /$ ton in 2003 and had reached $\$ 950 /$ ton by the end of 2005 .

Regarding profitability, all five of Japan's integrated steel makers posted record high profits in their interim statements announced in September 2005, and are also expected to set new records for the year as a whole. This strong performance was attributable to the fact that the improvement in sales prices was sufficient to absorb cost increases due to the rise in raw material prices and other factors, in combination with continuing rationalization efforts. The five spe- cial steel makers also announced record high earnings in their interim statements in September 2005, and many of electric arc furnace steel makers are continuing to enjoy high profits.

Trends in steel-using industries: By industry, the construction industry reported the start of construction of 1236 thousand new residential units, for an increase of 47 thousand from 2004. The total area of construction starts was 186.08 million $\mathrm{m}^{2}$, for an increase of $4.57 \mathrm{~m}^{2}$ from 2004 . In 2005 , the automobile industry improved on its strong performance in 4-wheel vehicles in 2004, with production of 10.8 million units, for an increase of an 0.3 million unit and exceeding 10 million units for the 4 th consecutive year. In general machinery, production indexes exceeded those for 2004, supported by firm private-sector demand, particularly in the manufacturing industries. In electric machinery, indicators continued to fall below the previous year during the first half of 2005, but the final results for the year exceeded 2004 due to favorable trends in consumer electronics (liquid crystal televisions, video cameras, etc.) and electronic components in the second half. In shipbuilding, the volume of orders received declined from 2004 due to the trend toward selective order acceptance. Nevertheless, construction 
activities continued on a high level, and companies have secured future orders covering a period of about 3 years.

Capital investment: The planned spending of the five integrated steel makers for FY2005 showed increases from FY2004 in all cases. In total, the five companies planned to invest $¥ 419.1$ billion, for a $26.5 \%$ increase. After peaking at more than $¥ 900$ billion in FY1992, the planned investment of the five integrated steel makers declined to a low of $¥ 260$ billion in FY2002, when it finally turned upward. In terms of content, the main direction of investment plans is reduction of bottlenecks and improvement of the product mix rather than large-scale new equipment investment. The following presents examples of main capital investment items during FY2005.

Planned blast furnace revamps included JFE Steel's West Japan Works (Fukuyama District) No. 4BF (scheduled for completion in the 1st quarter of FY2006), Sumitomo Metal's Kashima Works No. 3BF (May 2007), and Kobe Steel's Kakogawa Works No. 2BF (March 2007). In coke oven projects, Nippon Steel's Nagoya Works installed 25 coking chambers (August 2005) and JFE Steel is currently constructing Battery D as an addition to the Fukuyama No. 5 coke oven (scheduled for completion in June 2006). Planned construction of new facilities to strengthen product lines includes a new continuous galvanizing line (CGL) at Nippon Steel's Hirohata Works (to be completed in the 2nd half of FY2006), a new CGL at JFE Steel's Fukuyama (2nd half of FY2006), a new continuous pickling line at JFE's East Japan Works (Keihin District) (2nd half of FY2006), a new CGL and continuous pickling line at Sumitomo Metal's Kashima Works (November 2006), and No. 5 bloom continuous caster at Kobe Steel's Kobe Works (August 2006).

The special steel makers also plan to expand capital investment in order to cope with increased demand for automotive products. At Aichi Steel, a new forging shop is under construction at Chita Works and will begin operation during FY2006. Mitsubishi Steel Manufacturing plans to increase production of special steel powders and automotive parts, while Sanyo Special Steel Co. will strengthen its processing capacity for steel tubes and other products by improving its electric arc furnace. These companies are maintaining full production, as strong order receiving is expected to continue for the foreseeable future. Among electric arc furnace makers of ordinary steel, Tokyo Steel Manufacturing has formally announced that it will construct a new steel works in Tahara City, Aichi Prefecture. This investment is predicted to exceed $¥ 100$ billion, and operation is expected to begin at the earliest in 2009.

Environmental protection: In addition to $\mathrm{CO}_{2}$ reduction, which is already the subject of intense efforts, "chromate-free" has recently become a keyword in the media. At the beginning of the year, Kobe Steel became the first steel maker to announce that it will completely phase out chromate (hexavalent $\mathrm{Cr}$ : $\mathrm{Cr}(\mathrm{VI})$ ) treatment in all steel products, and Japan's other makers have also announced a shift to chromate-free electrogalvanized and hot-dip galvanized steel sheets. During FY2005, chromate-free production is expected to be achieved with substantially $100 \%$ of electrogalvanized sheets and close to $100 \%$ of hot-dip galvanized sheets. These efforts respond to the rapidly rising demand for a changeover to products which contain no $\mathrm{Cr}(\mathrm{VI})$, in view of the approaching implementation of the EU's RoHS and EVL Directives (RoHS: Restriction of the use of certain hazardous substances in electrical and electronic equipment, EVL: End-of-life vehicle).

In responding to $\mathrm{CO}_{2}$ reduction, all of Japan's steel makers are diligently promoting energy saving countermeasures in accordance with the Voluntary Action Plan adopted by the Japan Iron and Steel Federation (JISF). According to a report by the JISF, in spite of a $2 \%$ increase in crude steel production, $\mathrm{CO}_{2}$ emissions in the iron and steel industry in FY2004 decreased by a total of 5\% in comparison with the 1990 baseline, and energy saving efforts accounted for a $7 \%$ reduction. In July, the JISF and the China Metal Industry Society jointly held a "Japan-China Iron and Steel Industry Technical Exchange Conference on Environmental Protection and Energy Saving" in Beijing in order to contribute to the sustained growth of the steel industries in the two countries and solution of global environmental problems. A memorandum of understanding in the names of the Chairmen of the two organization was signed, confirming the intention of the two sides to conduct ongoing exchanges on environmental protection and energy saving in the future. Among other environmental topics, Nippon Steel and Mitsubishi Corporation jointly announced a "Clean Development Mechanism (CDM)" project in China aimed at reducing flon gases.

Technical development: As one topic related to technical development, in April 2005, the Iron and Steel Division of Japan's Ministry of Economy, Trade and Industry (METI) prepared and published a "Iron and Steel Technology Strategy Roadmap" laying out directions and issues for iron and steel technology. The roadmap makes it possible to extract key technical issues and provides an overview of the needs, purposes, etc. of the respective technical tasks. As its purposes, in addition to its usefulness in the technical strategies of iron and steel makers, it is also intended to ensure that these technical issues are reflected in the Japanese government's Science \& Technology Policy. Among trends in technical development by Japan's various steel makers, in 2005, continuing from the previous year (as will also be discussed later), steel makers placed central importance on technical development for reducing manufacturing costs and energy saving, while also remaining committed to global environment protection. As one distinctive move, in August, JFE Steel established a Customers' Solution Laboratory (CSL) at East Japan Works (Chiba District), which is the first such initiative in the Japanese steel industry. The objectives of the CSL are to contribute to marketing activities in the automotive field and to the development of next-generation automobiles by the company's customers.

Labor-related issues: The Law concerning Stabilization of Employment of Older Persons was revised and takes effect in April 2006. In response to this, the respective steel makers have begun moves to raise the upper limit age for reemployment to 65 . Furthermore, as many steel makers are providing historically high lump-sum payments accompanying the strong corporate performance mentioned above, that the Japan Federation of Basic Industry Workers' Unions, which includes unions in the steel industry, ship- 
building industry, heavy industry, and others, has been reported to begin coordinating its efforts based on a demand for a "wage improvement" of $¥ 3000 \sim 5000$ /employee in anticipation of this year's spring labor negotiations. If realized, this will be the first wage increase in the steel industry in 6 years.

Outlook for the iron and steel industry in 2006: In the coming year, China is expected to increase crude steel production by 40 million tons, with moderate increases also expected in other countries. On the other hand, the JISF foresees a very small decrease in Japanese crude steel production, to 111.90 million tons. The expansionary tone in the world economy and recovery in the Japanese economy will be sustained, and demand for iron and steel will remain firm. However, total steel exports are seen as decreasing from the previous year due to prioritization of domestic demand and price considerations. Key points which must be watched are the effects of rapid increases in oil prices and trends in China. In particular, from the viewpoint of stabilization of raw material prices and conditions in the steel market, it will be necessary to see to what extent China's "Development Policy for the Iron and Steel Industry" and similar moves are effective. In addition, at the beginning of 2006, the shocking news that Mittal Steel, which is now the world's largest steel maker, proposed purchase of Arcelor, which is the world's No. 2 company, and Arcelor had rejected this bid has circulated around the world. Under these conditions, for the time being, it will be impossible to ignore new trends in the worldwide consolidation of the steel industry.

\section{Technology and Equipment}

\subsection{Ironmaking}

In 2005, Japanese pig iron production was 83.06 million tons, which represented a $0.1 \%$ increase from 2004 and exceeded 80 million tons for the 4th consecutive year. Average blast furnace productivity also showed a moderate increase, at $2.03 \mathrm{t} /\left(\mathrm{m}^{3} \cdot \mathrm{d}\right)$ in comparison with $2.02 \mathrm{t} /\left(\mathrm{m}^{3} \cdot \mathrm{d}\right)$ in 2004 .

The trends in individual blast furnace revamping projects are shown in Table 2. Mentioning the operation state of 2005 , the number of blast furnaces in operation was 28 units the same as that at the end of 2004. JFE Steel's West Japan Works (Fukuyama District) No. 5BF was revamped in a short period of 58 days in February-March 2005, and its inner volume was enlarged from 4664 to $5500 \mathrm{~m}^{3}$. As a result, at the end of 2005, Japan had a total of 7 blast furnaces with inner volune of $5000 \mathrm{~m}^{3}$ or more. In response to further increases in demand for steel and the need to increase productivity, the blast furnaces with inner volume of $5000 \mathrm{~m}^{3}$ class are expected to increase such as the revamp plan of the JFE's Fukuyama No. 4BF.

The prices of ironmaking-related raw materials have remained on a high level. In particular, because price increases for coking coal and coke result in increased steel manufacturing costs, supply-and- demand trends have attracted attention.

As shown in Fig. 2, the pulverized coal injection (PCI) rate of blast furnaces in 2005 decreased slightly from the previous year, to an average of $118.2 \mathrm{~kg} / \mathrm{ton}$, and the coke ratio also decreased slightly, to $378 \mathrm{~kg} / \mathrm{ton}$.

As countermeasures to increase coke production capacity, startups and plans for new equipment were announced. Nippon Steel's Nagoya Works constructed and started up 25 chambers at its coke oven, and JFE Steel's West Japan Works (Fukuyama District) is planning to complete the construction of 55-chambers at No. 5 coke oven Battery D during 2006. Nippon Steel is also studying practical application of the next-generation coke oven developed in SCOPE 21 at its Oita Works. Mitsui Mining Co., Ltd. is revamping 46 chambers at Battery $1 \mathrm{~A}$, which is currently

Table 2. Relining of blast furnaces in Japan.

\begin{tabular}{|c|c|}
\hline & Blast furnace \\
\hline 2005 & $\begin{array}{l}\text { JFE steel West Japan Fukuyama No.5 BF } \\
\text { - Blow off January 30, blow in April } 31 \\
\quad \text { (Work period: } 58 \text { day) } \\
\text { - Enlargement of inner volume from } 4664 \text { to } 5500 \mathrm{~m}^{3}\end{array}$ \\
\hline $\begin{array}{l}\text { Scheduled for } \\
\text { the future }\end{array}$ & $\begin{array}{ll}\text { JFE steel West Japan Fukuyama No.4 BF: } & (2006) \\
\text { Nippon steel Nagoya No. } 1 \text { BF: } & (2007) \\
\text { Kobe steel Kobe No.3 BF: } & (2007) \\
\text { Kobe steel Kakogawa No. } 2 \text { BF } & \end{array}$ \\
\hline
\end{tabular}

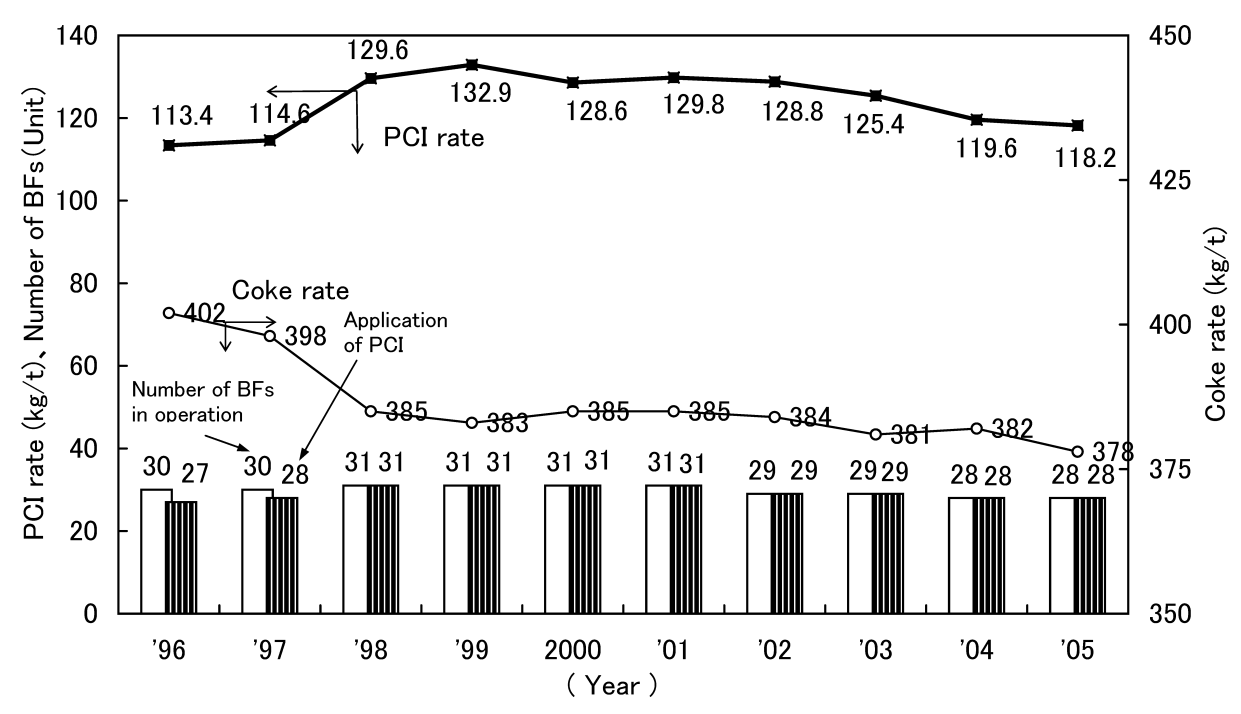

Fig. 2. Increase in pulverized coal rate injected into blast furnace in Japan. Souce: The Japan Iron and Steel Federation. 
shut down, and expects to restart this facility during FY2006, and Sumikin Iron \& Steel corporation has announced plans for renovation/replacement of its coke ovens, targeting a 2009 startup.

\subsection{Steelmaking}

As the condition of steelmaking in 2005, the results of converter operation and electric furnace operation are shown in Tables 3 and 4, respectively. In the converter area, production indexes maintained a high level from 2004. Because the blending ratio of pig iron and hot metal decreased, continuing from 2004, a further increase in the use of cold iron sources (scrap) can be inferred. The ratio of vacuum treatment in converter steelmaking continued to increase, exceeding $75 \%$ for the first time. Although the results of electric furnace operation were substantially the same as in 2004, the alloy steel ratio reached $40 \%$ in this process for the first time. This, together with the high ratio of vacuum treatment in converter shops, suggests that there is an accelerating orientation toward high performance steel products.

Figure 3 shows the ratio of continuous cast slabs in steel ingots for rolling. The ratio for plain carbon steel was
$99.8 \%$ for the 3 rd consecutive year, while that for special steels increased by $0.2 \%$ from the previous year, to $94.6 \%$.

As trends in steelmaking-related technology and equipment, the Japanese steel industry is continuing its efforts to cope with stricter/more advanced product quality requirements, reduction of loads on the global environment, and high demand, among other conditions. The following may be mentioned as the main equipment expansion projects which were started up during the year.

In the field of melting, JFE Bars \& Shapes Corporation revamped the $150 \mathrm{t}$ electric arc furnace (EAF) at its Himeji Works, introducing a raw material preheating-type EAF using waste heat. This plant was started up in November. Because the scrap preheating shaft is connected directly to the furnace in this new-type EAF, waste heat loss is greatly reduced by heat recovery, and a large reduction in electric power consumption and substantial improvement in productivity are expected as a result of improved thermal efficiency. Moreover, adoption of a closed-type furnace enables sure treatment of off-gas (see Topics).

To cope with the growth in demand for special steel, Nippon Steel's Muroran Works purchased the $100 \mathrm{t}$ direct current EAF (DC-EAF) equipment from Mitsubishi Steel

Table 3. Operation performance of converter.

\begin{tabular}{lllllllll}
\hline & 2002 & 2003 & 2004 & 2005 & & \multicolumn{2}{c}{2005} \\
& Average & Average & Average & Jan.-Mar. & Apr.-Jun. & Jul.-Sep. & Oct.-Dec. & Average \\
\hline Productivity index per steelmaking hour* & 105 & 105 & 104 & 104 & 104 & 106 & 106 & 105 \\
Steelmaking time index per tap to tap* & 99 & 100 & 102 & 101 & 101 & 100 & 100 & 101 \\
Pig iron mixing ratio(\%) & 91.2 & 89.7 & 89.1 & 87.9 & 88.3 & 88.7 & 89.6 & 88.6 \\
Hot metal mixing ratio $(\%)$ & 90.0 & 88.2 & 87.7 & 86.2 & 86.4 & 87.1 & 88.6 & 87.1 \\
Oxygen consumption $\left(\mathrm{Nm}^{3 / \mathrm{t})}\right.$ & 57.4 & 56.5 & 57.2 & 58.3 & 58.1 & 57.5 & 57.2 & 57.8 \\
Ratio of continuous cast steel(\%) & 99.0 & 98.8 & 98.8 & 98.8 & 98.8 & 98.7 & 98.6 & 98.7 \\
Ratio of vacuum treated steel(\%) & 68.1 & 71.5 & 72.7 & 74.9 & 75.2 & 75.5 & 75.9 & 75.4 \\
\hline
\end{tabular}

* The index is based on the average of 1998 2000,100

Source: The Iron and Steel Federation

Table 4. Operation performance of electric furnace.

\begin{tabular}{lllllll}
\hline & 2002 & 2003 & 2004 & 2005 & 2005 & 2005 \\
& Average & Average & Average & Jan.-Jun. & Jul.-Dec. & Average \\
\hline Productivity index per steelmaking hour* & 106 & 108 & 110 & 110 & 108 & 109 \\
Electric power consumption per ton of good ingot $(\mathrm{kWh} / \mathrm{t})$ & 411.9 & 420.2 & 423.9 & 423.8 & 427.9 & 425.8 \\
Oxygen consumption per ton of good ingot $\left(\mathrm{Nm}^{3 / \mathrm{t}}\right)$ & 19.9 & 19.5 & 19.9 & 19.9 & 20.1 & 20.2 \\
Yield of good ingots (\%) & 91.9 & 91.7 & 91.5 & 91.2 & 91.5 & 91.3 \\
Ratio of good continuously cast steel (\%) & 88.3 & 87.0 & 88.4 & 88.0 & 87.1 & 87.6 \\
Ratio of alloy steel (\%) & 35.7 & 37.8 & 38.1 & 40.2 & 39.8 & 40.0 \\
\hline
\end{tabular}

* The index is based on the average of 1998 2000, 100

Source: The Iron and Steel Federation

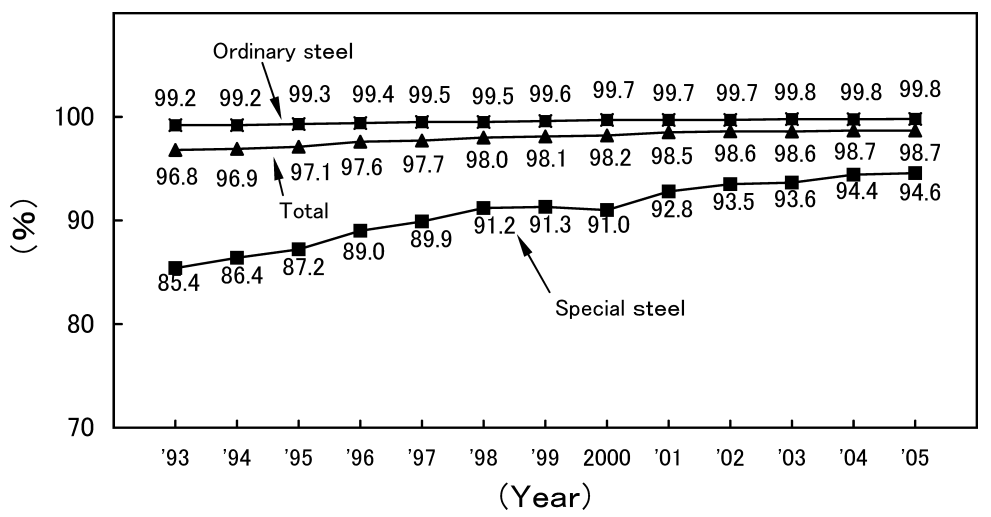

Fig. 3. Change of ratio of continuous casting production. Source: The Japan Iron and Steel Federation. 
Manufacturing, which was shut down in 2001, and restarted this equipment in July. Integrated production capacity will be increased by approximately 20000 tons/month by utilizing the excess rolling capacity at Mitsubishi Steel's Muroran Works special steel plant.

In the field of refining, Nippon Steel started operation of a dephosphorizing treatment furnace at Kimitsu Works No. 2 steelmaking shop in April. This enabled stable production of high-grade steel (low-P steel) by a refining process using a 2-furnace method (dedicated furnace-type converter hot metal pretreatment process) comprising the above-mentioned dedicated de-P furnace and a decarburizing furnace. This technology is also expected to be effective in environmental improvement by reducing the amount of slag generation, etc.

\subsection{Plates, Pipes, and Long Products}

In plate manufacturing, JFE Steel has developed various kinds of high strength steel plates with excellent weldability and low temperature toughness by applying its Heat-treatment On-line Process (HOP), which was introduced at West Japan Works (Fukuyama District). HOP employs a high efficiency induction heating method in which plates are heating by passing through an electromagnetic coil (inductor). (See Table 10, New products.)

Nippon Steel's Kimitsu and Oita Works installed high efficiency energy saving-type heating furnaces which enable waste heat recovery and are capable of coping with diverse heating conditions by adopting regenerative burners.

In the field of bar products, Sumitomo Metals (Kokura) upgraded its direct inspection and conditioning line. This is an automatic inspection line which features an arrangement including a straightner, chamfering machine, mixed product checking device, length meter, magnetic flux leakage flux tester (MLFT), and ultrasonic tester (UT), and responds to increased production of high quality special steel bars for automotive applications.

Daido Steel, subsidized by NEDO (the Japanese government's New Energy and Industrial Technology Development Organization), established a technology for high-level addition of $0.6 \%$ nitrogen, which is an effective element for improving hardness and corrosion resistance, to stainless steel using a pressurized induction melting casting process developed independently by Daido, and developed a steel grade with corrosion resistance close to that of the seawater-resistant steel such as SUS316, while maintaining hardness equivalent to that of conventional high strength stainless steel.

\subsection{Steel Sheets}

In hot rolling, JFE Steel's West Japan Works (Fukuyama District) introduced a slab sizing press at No. 2 hot strip mill. This technology expands slab width reduction to $300 \mathrm{~mm}$, which is double the conventional amount. Because this makes it possible to produce hot strips of various sizes from the same slab, introduction of the slab sizing press has increased the plant's monthly production capacity from 300000 to 360000 tons, responding to increased demand for steel sheets for automobiles and electrical appliances, which are main products.

As new construction related to pickling, cold rolling, and coating, JFE Steel's East Japan Works (Keihin District) announced a new continuous pickling line (capacity: 1.2 million tons/year) which will be connected directly to an existing cold rolling line. New CGLs were announced for JFE Steel's West Japan Works (Fukuyama District) (600000 tons/year) and Nippon Steel's Hirohata Works (approx. 360000 tons/year). All of these new facilities are scheduled to begin operation in the second half of 2006. Other major projects include the construction of a continuous pickling line and new CGL at Sumitomo Metal's Kashima Works, which was announced in 2004, and CGL renovations at Nippon Steel's Nagoya and Kimitsu Works, which are scheduled for startup in 2006. These various projects will greatly increase coated steel sheet production capacity.

In response to the ban on $\mathrm{Cr}(\mathrm{VI})$ and other designated harmful substances in electrical and electronic equipment sold in the EU after July 2006 under the RoHS Directive, all Japanese steel makers have expanded their menus of chromate-free steel sheets, and have strengthened production equipment and developed new corrosion test methods applicable to chromate-free products.

\subsection{Measurement, Testing, and Analysis}

Sumitomo Metal developed an auto-turning system to control the periodical mold level fluctuations in the continuous caster and applied this technology to all continuous casters at Kashima Works.

Responding to requirements for high strength and greater thickness in linepipe materials accompanying use in more severe environments, Nippon Steel introduced Japan's largest drop weigh tear tester, enabling fracture testing of plate thicknesses as large as $60 \mathrm{~mm}$.

On the other hand, a succession of testing and analysis devices for the microscopic region were also introduced. For example, these included a nano incidenter (precision stage) at Kobelco Research Institute, Inc. which enables measurement of hardness and Young's modulus in the micro region, and as micro analysis devices, a laser ICP mass spectrometer (LA-ICP-MS) at JFE Techno-Research, a micro X-ray fluorescence spectrometer $(\mu$-XRF $)$ at Sumitomo Metal Technology Inc., and an electron probe microanalyzer with a high brightness field emission electron gun (FE-EPMA) at Daido Bunseki Research, Inc.

\subsection{Environmental Protection}

During 2005, environmental protection efforts by Japan's steel makers were characterized by an even higher level of activity than heretofore, and it can perhaps be said that these have become a permanent feature of corporate policy. Companies are engaged in the development of products which stipulate environment-friendliness and cooperation with external companies and local governments using the existing infrastructure of the steel works. In waste treatment, companies are attempting to utilize waste as byproducts and supply clean energy using the existing equipment in the works. The industry has also expanded overseas environment-related technical cooperation and project development. Main technologies include the following.

Kobe Steel developed a technology which enables high efficiency heat storage/recovery of waste heat with temperatures under $200^{\circ} \mathrm{C}$, and transportation by trailer, using the 
Table 5. Contents of technology export and technology import. (Term: January 1, 2005-December 31, 2005)

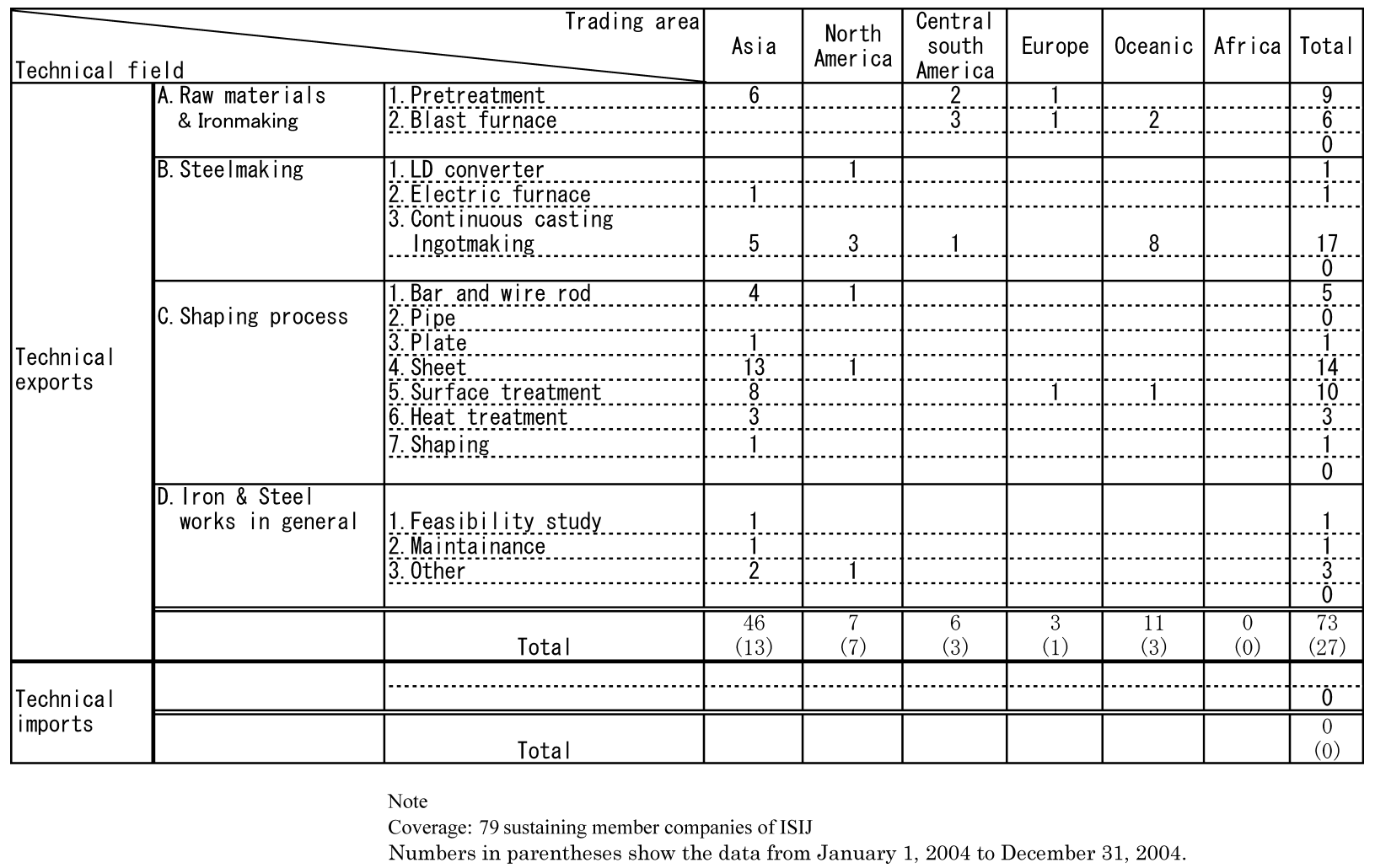

artificial sweetener Erythritol. Assuming a temperature close to $200^{\circ} \mathrm{C}$, use in air-conditioning is possible by combining this heat/cooling medium with an absorption (refrigerating) machine. Thus, a dramatic expansion in application is expected.

Since 1989, JFE Steel has been involved in research on DME (dimethyl ether), which can be synthesized from natural gas, coal, and biomass. As distinctive features, DME contains no sulfur and does not generate particulate matter (PM) when used in diesel engines. To date, road tests have been conducted in the company's steel works, but tests on public roads with a truck mounted with a crane began in November 2005. Tests to verify the possibility of use as an alternative fuel for power generation are scheduled to begin in 2006.

All companies are also continuing to develop new chromate-free products, as already mentioned in the section on coating, and new products/methods of using blast furnace slag.

In the environmental field, the respective companies are also making diligent efforts in $\mathrm{R} \& \mathrm{D}$ on related technologies with cooperating universities using public funding, as will be introduced in Sec. 4.2.

\section{Technology Exports/Technology Imports}

A breakdown of technology trade during the calendar year period of 2005 is shown in Table 5, which presents the results of a survey of 79 ISIJ Sustaining Member companies. Technology exports increased substantially, from 27 items in 2004 to 73 items in 2005. As in 2004, technology imports were zero. Among export regions, Asia accounted for $63 \%$ of the total, followed by Oceania, North America, and Central and South America. The largest technical field was processing and treatment (47\%), followed by steelmaking. Figure 4 shows the balance of payments for trade in technology in the iron and steel industry up to FY2004. Consideration received for technology exports increased by $23 \%$ from the previous year, while consideration paid for technology imports was flat.

\section{Research and Development}

\subsection{Research Expenditures/Number of Researchers}

The trends in the ratio of corporate research expenditures to sales, research expenses per full-time researcher, and number of full-time researchers per 10000 employees according to the "Scientific and Technical Research Survey Report" published by the Statistics Bureau, Ministry of Internal Affairs and Communications, are shown in Figs. 5-7.

Looking first at changes in the ratio of research expenditures to sales, although this item turned positive for all industries in FY2004, the iron and steel industry showed a continuing decreasing trend. Research expenditures in the steel industry declined for three consecutive years, from $¥ 135345$ million in 2001 to $¥ 129660$ million in 2002 , and $¥ 128032$ million in 2003, which was followed by a modest increase to $¥ 135087$ million in 2004 .

The number of full-time researchers per 10000 employees has shown an increasing tendency over the long term amid rationalization of production division employees. The number of full-time researchers in the steel industry was 4238 in 2004, which increased to 4607 in 2005. However, the breakdown showed a decrease of 29 persons in companies with capitalization of $¥ 10$ billion and an increase of 

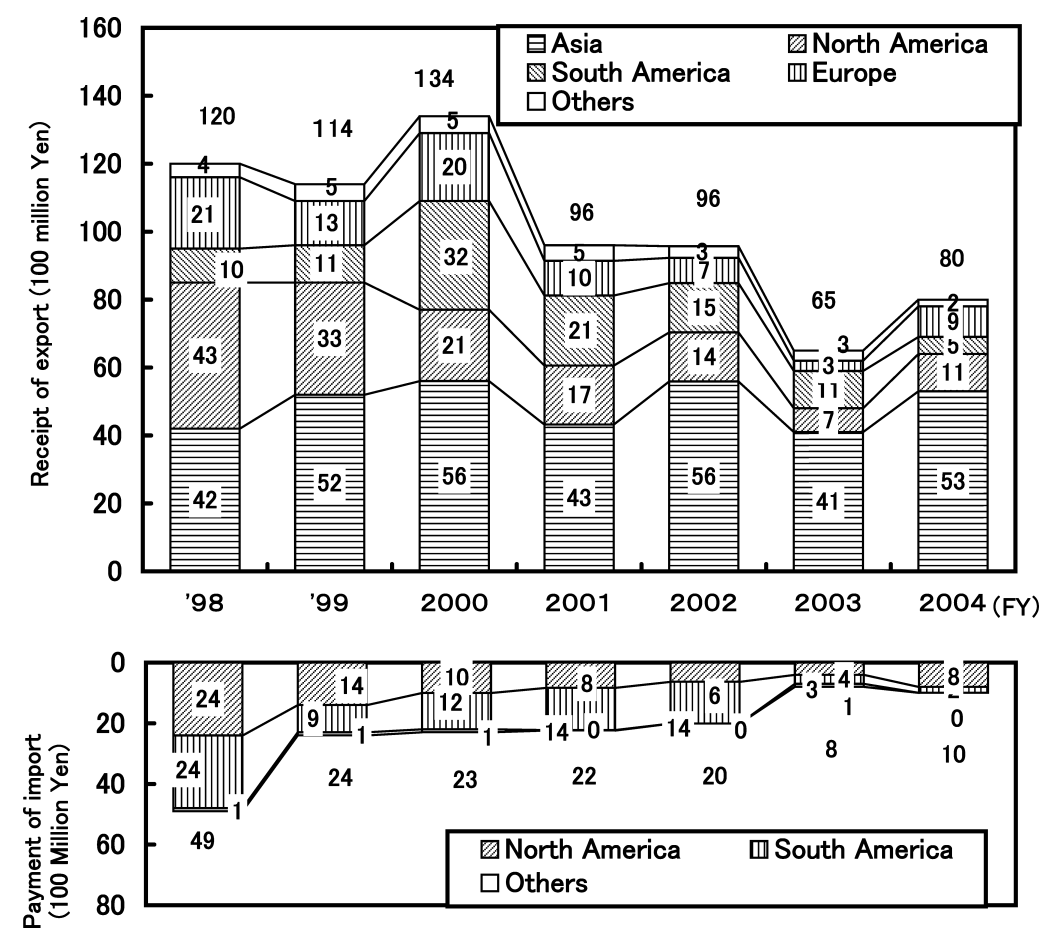

Fig. 4. Balance of technology trade of steel.

Source: "Report on the Survey of the Research and Development", Statistic Bureau, Ministry of Public Management, Home Affairs, Post and Telecommunications.

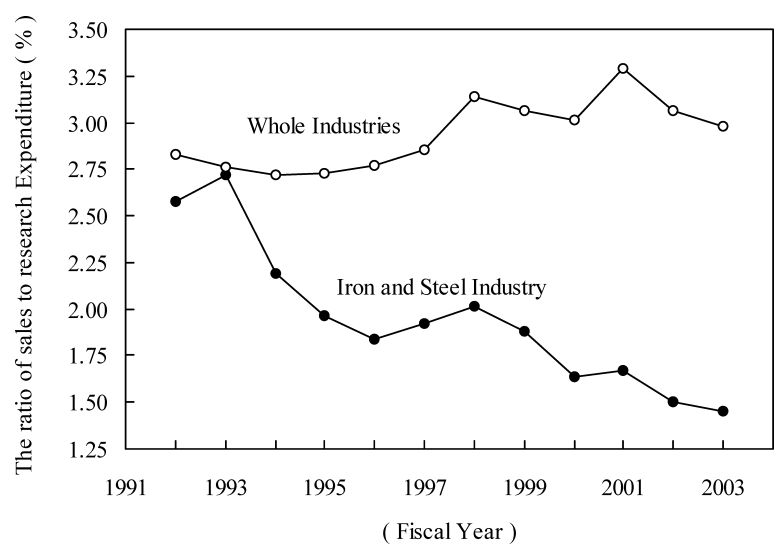

Fig. 5. Trend of the ratio of sales to research expenditure. Source: "Report on the 2004 Survey of the Research and Development", Statistic Bureau, Ministry of Public Management, Home Affairs, Post and Telecommunications.

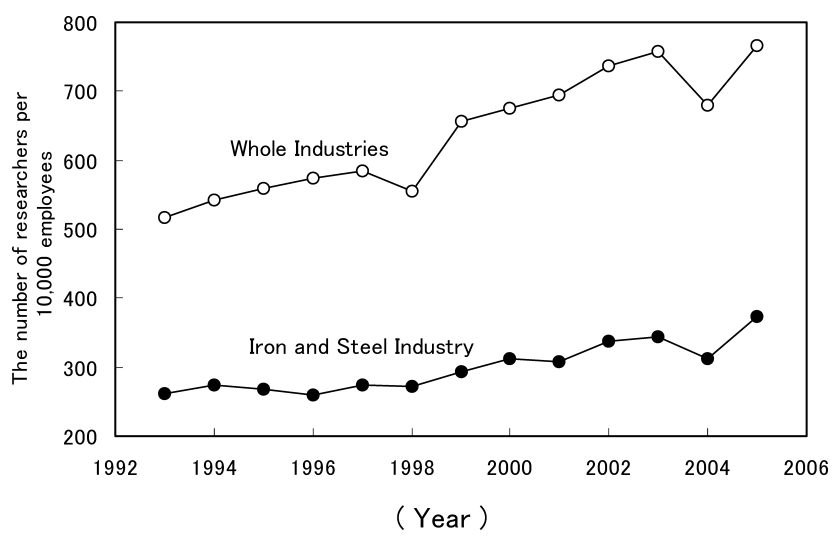

Fig. 6. Trend of the number of researchers per 10000 emploees. Source: "Report on the 2004 Survey of the Research and Development", Statistic Bureau, Ministry of Public Management, Home Affairs, Post and Telecommunications.

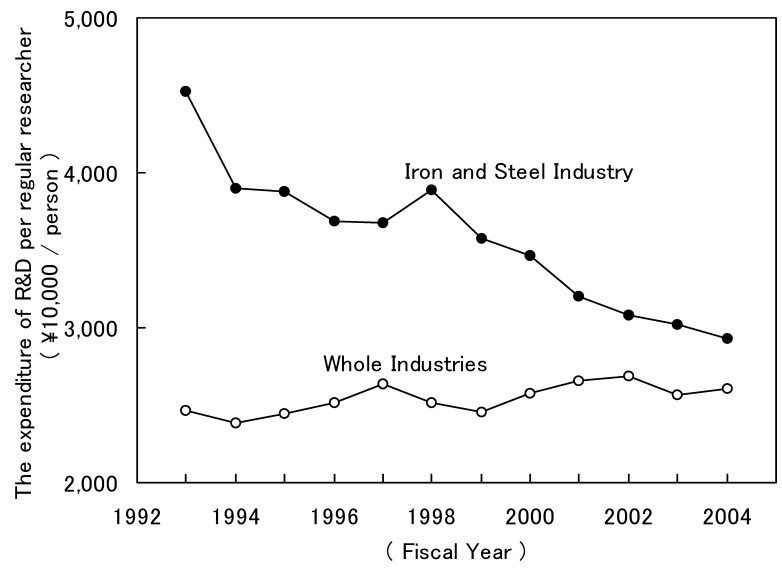

Fig. 7. Trend of the expenditure of R\&D per regular researcher. Source: "Report on the 2004 Survey of the Research and Development", Statistic Bureau, Ministry of Public Management, Home Affairs, Post and Telecommunications.

251 persons in companies with capitalization of $¥ 10$ million- $¥ 100$ million.

Research expenses per full-time researcher in the steel industry exceeded those in all industries, but the decreasing tendency in the steel industry continued as before. This item fell below the important $¥ 3000$ thousand level for the first time, declining to $¥ 2932$ thousand, and is continuing to approach that in all industries ( $¥ 2603$ thousand).

\subsection{Trends in Research and Development Using Pub- lic Funds}

Iron and steel-related research/technical development topics being carried out with public funds were surveyed at the ISIJ's principal Sustaining Member companies. The main results are shown in Table 6. Member companies are 
Table 6. Examples of public funded research projects for steel industry in Japan.

\begin{tabular}{|c|c|c|c|c|}
\hline Category & Subjects & Source of funds and commission & $\begin{array}{l}\text { Beginning } \\
\text { fiscal year }\end{array}$ & $\begin{array}{l}\text { Ending } \\
\text { fiscal year }\end{array}$ \\
\hline \multirow{9}{*}{$\begin{array}{l}\text { Process } \\
\text { / Facility }\end{array}$} & $\begin{array}{l}\text { Hydrogen Amplification Technology Development using Byproduct Gas in the Steelmaking } \\
\text { Process (Hot COG: Coke Oven Gas) as Source }\end{array}$ & NEDO & 2001 & 2005 \\
\hline & $\begin{array}{l}\text { Development of Recycling Technology for Ferrous and Plastic Wastes by Electric Arc Furnace } \\
\text { Steelmaking Technology }\end{array}$ & NEDO & 2002 & 2005 \\
\hline & $\begin{array}{l}\text { Support Project for Industries for Increasing the Efficient Use of Energy } \\
\text { (Introduction of the electric arc furnaces with the scrap preheating shaft to recover waste heat*) }\end{array}$ & NEDO & 2004 & 2005 \\
\hline & $\begin{array}{l}\text { Promotion of natural gas adoption for plants using intensive energy } \\
\text { ( The reheating furnace for middle size seamless pipes, boiler) }\end{array}$ & METI, The Japan gas association & 2004 & 2006 \\
\hline & $\begin{array}{l}\text { Development of Practical Application of Technology of Energy-Saving Recovery of Metal } \\
\text { Components in High Temperature EAF Exhaust Gases }\end{array}$ & NEDO & 2004 & 2007 \\
\hline & $\begin{array}{l}\text { Support Project for Industries for Increasing the Efficient Use of Energy } \\
\text { (Waste heat recovery in NH3 recovery plants from coke oven gas *) }\end{array}$ & NEDO & 2005 & 2005 \\
\hline & $\begin{array}{l}\text { Support Project for Industries for Increasing the Efficient Use of Energy } \\
\text { (Introduction of the high efficient compressor for air separation plants*) }\end{array}$ & NEDO & 2005 & 2006 \\
\hline & $\begin{array}{l}\text { Support Project for Industries for Increasing the Efficient Use of Energy } \\
\text { (Waste plastics injection into blast furnaces by the heat treatment pulverization *) }\end{array}$ & NEDO & 2005 & 2005 \\
\hline & Development of innovative process technology of advanced titanium alloy* & METI, JRCM & 2005 & 2008 \\
\hline \multirow{4}{*}{$\begin{array}{l}\text { Elemental } \\
\text { technology }\end{array}$} & Development of the Ferrous Nano-Metal Project & NEDO & 2001 & 2005 \\
\hline & Development of Welding Technology of Steel Structures for Energy Conservation & NEDO & 2003 & 2005 \\
\hline & Development for Safe Utilization and Infrastructure of Hydrogen & NEDO & 2003 & 2007 \\
\hline & $\begin{array}{l}\text { Research on preventive and remedial measures for oil spill, (microbiologically influenced } \\
\text { corrosion and bioremediation) }\end{array}$ & $\begin{array}{l}\text { METI, NEDO, National institute } \\
\text { of technology and evaluation }\end{array}$ & 2005 & 2007 \\
\hline \multirow[b]{2}{*}{ Product } & Development of Innovative Magnetic Materials for Reducing Transformer Power Losses & METI, NEDO & 2002 & 2004 \\
\hline & $\begin{array}{l}\text { Kyoto protocol target achievement plan } \\
\text { Development of high strength austenitic steel for main steam pipe of ultra super critical power } \\
\text { plant }\end{array}$ & $\begin{array}{l}\text { Research institute of innovative } \\
\text { technology for the earth }\end{array}$ & 2005 & 2005 \\
\hline
\end{tabular}

The subjects attaching asterisks ${ }^{*}$ ) were translated by the ISIJ secretariat.

METI: Ministry of Economy, Trade and Industry,

NEDO: New Energy and Industrial Technology Development Organization

JRCM: The Japan research and development center for metals

Table 7. Technology creation activities of Technical Committee, Interdisciplinary Technical Committee, and Research Group.

\begin{tabular}{|l|l|}
\hline \multicolumn{1}{|c|}{$\begin{array}{c}\text { Technology creation } \\
\text { activities }\end{array}$} & \multicolumn{1}{c|}{ Content of activities } \\
\hline Technical Committee & $\begin{array}{l}\text { The Technical Committees aim to improve on-site technical standard and to promote } \\
\text { technological exchange for iron and steel production, as well as engage in extraction and } \\
\text { research of technical topics in each field. 19 Technical Committees that encompass the } \\
\text { entire spectrum of iron and steel manufacturing are active, and engineers and researchers } \\
\text { of iron and steel companies as well as university researchers participate in the } \\
\text { Committees. Meeting of the Committees is held once or twice a year, and Technical } \\
\text { Subcommittees that focus on discussing technical topics are set as subordinate } \\
\text { organization to carry out technology creation activities. }\end{array}$ \\
\hline $\begin{array}{l}\text { Interdisciplinary } \\
\text { Technical Committee }\end{array}$ & $\begin{array}{l}\text { To make technical examinations and surveys on future development and solution about } \\
\text { interdisciplinary technological problems within the iron and steel industry and with other } \\
\text { industries. Two Committees are active Control of Second-phase Particles in Structural } \\
\text { Steels for Improved Properties, Desirable Steel Materials for Automobiles (PhaseIV)) }\end{array}$ \\
\hline Research Group & $\begin{array}{l}\text { To conduct the joint research on specific and important subjects for iron and steel industry } \\
\text { based on the needs from industry and seeds from academia. As of end-February, 2006, 24 } \\
\text { Research Group are active. }\end{array}$ \\
\hline
\end{tabular}

involved in numerous topics in the fields of energy and the environment and nanomaterials, among others.

\section{Technology Creation Activities in the ISIJ}

\subsection{New Activities}

The Division of Environmental and Energy Technology (3 forums), which was established in the ISIJ's Academic Society as an interdisciplinary division, entered its 2 nd year of activities, and the number of registered members reached 305 as of the end of January 2006 (including approximately 50 non-ISIJ members). This division was active in holding study groups, symposiums, international sessions, and preview sessions at conferences. In particular, the symposium "Frontline of Resource and Energy Supply and Demand Conditions Surrounding the Japanese Iron and Steel Industry," which was held jointly by the Division of Environmental and Energy Technology and the Division of Social Engineering on Iron and Steel Industry, received favorable reviews.
Beginning in January 2006, the ISIJ's English-language journal "ISIJ International" (from Jan. 2005 issue) will be carried by Japan Science and Technology Information Aggregator, Electronic (J-Stage), which is the web homepage of the Japan Science and Technology Agency. The ISIJ also plans to make back issues from 1981 onward available upon completion of archiving work. Listing of the ISIJ's Japanese-language journal, "Tetsu-to-hagané" (from No. 1 issue) in the paper information service of the National Institute of Informatics was also completed in 2005.

\subsection{Technical Committees}

In the ISIJ, research on iron and steel production technologies and activities to increase awareness of important technical development issues are carried out mainly by the Technical Society. The classification and content of these activities is shown in Table 7. In particular, in the Technical Committees which promote activities specific to the ISIJ, each committee are divided into groups according to the 
Table 8. Activities of the Technical Committees.

\begin{tabular}{|c|c|}
\hline $\begin{array}{c}\text { Technical } \\
\text { Committee }\end{array}$ & $\begin{array}{l}\text { Common Subject, Particular Subject, Report from Technical Subcommittee, Special Lecture; } \\
\text { (1) Spring Meeting, (2) Autumn Meeting }\end{array}$ \\
\hline Ironmaking & $\begin{array}{l}\text { (1) Common subject "Stable high productivity operation of blast furnace and raw material design"; Open } \\
\text { topic research presentation; Lecture "Theoretical analysis of changes in burden descent in the shaft," } \\
\text { "Dynamics of melt in the dropping zone" }\end{array}$ \\
\hline Coke & $\begin{array}{l}\text { (1) 10th Reporting of Production Technology } \\
\text { (2) Common subject "Blending and coke quality control in high productivity operation"; Open topic } \\
\text { research presentation; Special lecture "New evaluation method for coke fracture strength," "Chinese iron } \\
\text { and steel industry" }\end{array}$ \\
\hline Steelmaking & $\begin{array}{l}\text { (1) Common subject "Operating technology and quality improvement technology supporting high } \\
\text { efficiency continuous casting"; Invitational lecture "Why electromagnetism is interesting today" } \\
\text { (2) Common subject "Environment-friendly refining technology"; Open topic research presentation; } \\
\text { Invitational lecture "Proposal of element technologies for an environment-friendly steel manufacturing } \\
\text { process using heterogeneous phase interface," "Necessity of inter-industry cooperation with the steel } \\
\text { works as core and key technologies for cooperation" }\end{array}$ \\
\hline $\begin{array}{l}\text { Electric } \\
\text { Furnace }\end{array}$ & $\begin{array}{l}\text { (1) Common subject "Improving productivity and maintaining quality in the casting process"; Special } \\
\text { lecture "Formation mechanism and countermeasures for surface defects of continuous cast slabs"; Open } \\
\text { topic research presentation } \\
\text { (2) Common subject "Problems and measures for stable operation"; Special lecture "Use technologies of } \\
\text { oxygen combustion" }\end{array}$ \\
\hline Special Steel & $\begin{array}{l}\text { (1) Common subject "Inclusion evaluation methods and operating technologies for inclusion reduction"; } \\
\text { Open topic research presentation; Invitational lecture "Relationship between inclusions/hydrogen and } \\
\text { ultra-long life in high strength steels"; Lecture "Recent research on the steelmaking process," "Melting } \\
\text { method for fine oxide particles by deoxidation"; Report on activities of joint Technical Subcommittee } \\
\text { activities; Interim report on YES (Young scientists Education Session) group } \\
\text { (2) Common subject "Recent improvement in ingot production techniques"; Open topic research } \\
\text { presentation; Invitational lecture "Development of production technology for large forging ingots"; } \\
\text { Lecture "Progress in quasi-solid prediction methods," "Morphology control for sulfides in steel formed } \\
\text { in quasi-solids" }\end{array}$ \\
\hline Refractories & $\begin{array}{l}\text { (1) Panel discussion "RH refractory relining"; Special lecture "History of refractories (centering on } \\
\text { refractory bricks for iron and steel up to pre-war period)" } \\
\text { (2) Joint meeting with the Technical Association of Refractories, Japan }\end{array}$ \\
\hline Heavy Plate & $\begin{array}{l}\text { (1) Plant operation status report; Special lecture "Subcontracting control" } \\
\text { (2) Common subject "Improvement of direct rolling ratio"; Plant operation status report; Staff Gr. } \\
\text { discussion "Direct rolling ratio"; Foreman Gr. discussion "Human resources training"; Production Dept. } \\
\text { General Manager discussion; Special lecture "Leveling theory" }\end{array}$ \\
\hline Hot Strip & $\begin{array}{l}\text { (1) Mill line operational result survey; Plant general status report; Foreman Gr. training session } \\
\text { "Responding to disaster-related trouble in the hot strip mill (earthquake, water shortage, power outage, } \\
\text { utility leaks, etc., excluding fire and typhoon)"; Special lecture "Effect of scale properties on surface } \\
\text { properties of steel products" } \\
\text { (2) Plant operation status report; Open topic research presentation; Foreman Gr. training session } \\
\text { "Activating voluntary control activities" }\end{array}$ \\
\hline Cold Strip & $\begin{array}{l}\text { (1) Plant operation status report; Presentation of case studies; Foreman Gr. discussion "Human resources } \\
\text { training and skill transmission" } \\
\text { (2) Plant operation status report; Presentation of case studies; Foreman Gr. discussion "Countermeasures } \\
\text { for prevention of mass rejects (mainly surface defects)"; Special lecture "Interim report of Research } \\
\text { Group for Analysis on Micro-plasticity in Temper Rolling for Steel Sheet" }\end{array}$ \\
\hline $\begin{array}{l}\text { Coated Steel } \\
\text { Sheet }\end{array}$ & $\begin{array}{l}\text { (1) Plant operation status report; Common subject "Energy saving"; Open topic research presentation; } \\
\text { Special lecture "Pursuit of ideal bath management in the CGL"; Foreman Gr. discussion "Safety" } \\
\text { (2) Plant operation status report; Technical Subcommittee report }\end{array}$ \\
\hline Large Section & $\begin{array}{l}\text { (1) Plant operation status report; Special lecture "Current status and future trends in rolling technology," } \\
\text { "Elucidation of the relationship between leveling shape and various parameters in the shape steel } \\
\text { leveling process by FEM" (special lecture organized jointly with the Division of Processing for Quality } \\
\text { Products, Section Forum) } \\
\text { (2) Plant operation status report; Open topic research presentation; Discussion by level }\end{array}$ \\
\hline $\begin{array}{l}\text { Bars and Wire } \\
\text { Rod Rolling }\end{array}$ & $\begin{array}{l}\text { (1) Plant operation status report; Open topic research presentation: Technical seminar "Technical } \\
\text { development strategy and management considered from personal R\&D experience," "Labor saving } \\
\text { equipment in the bars and wires mill and examples of introduction" } \\
\text { (2) Plant operation status report; Common subject "Capacity improvement"; Foreman Gr. topic "Safety } \\
\text { activities in the plant"; Special lecture "Sources and basic concepts of the Toyota production system," } \\
\text { "Frontline of crystal prediction simulation after rolling" }\end{array}$ \\
\hline $\begin{array}{l}\text { Steel Pipes and } \\
\text { Tubes }\end{array}$ & $\begin{array}{l}\text { (1) Special lecture "Asia/world energy outlook - The rapidly growing Asian economies and changing } \\
\text { energy supply-and-demand structure" } \\
\text { (2) Plant operation status report; Common subject with Pipe Technical Subcommittee "Productivity of } \\
\text { secondary process products in butt-welded pipes"; Common subject with small-diameter ERW pipe } \\
\text { "Manpower allocation in small-diameter ERW pipe and years of experience \& technology/skill } \\
\text { transmission," "Cold forming technology and equipment maintenance control," "UOE pipe production } \\
\text { parameters," Report of HLP Technical Subcommittee }\end{array}$ \\
\hline Rolling Theory & $\begin{array}{l}\text { (1) Topic "Development of rolling, forming, and other related technologies for steel sheet, plate, bar, rod, } \\
\text { sections, and pipe (particularly bar and wire rod rolling)"; Special lecture "Environmental problems in } \\
\text { automobiles and material-related tasks (centering on iron and steel materials," "Analytical technologies } \\
\text { for bar and wire rod rolling and drawing" } \\
\text { (2) Topic "Technical development related to processing processes and product development"; Special } \\
\text { lecture "Partial axial bulging process based on a new concept," "Examples of experience in hot rolling } \\
\text { control" }\end{array}$ \\
\hline $\begin{array}{l}\text { Heat Economy } \\
\text { Technology }\end{array}$ & $\begin{array}{l}\text { (2) Energy balance report; Open topic research presentation; Technical Subcommittee report; Special } \\
\text { lecture "Eco-network design method for reduction of } \mathrm{CO}_{2} \text { emissions" }\end{array}$ \\
\hline $\begin{array}{l}\text { Control } \\
\text { Technology }\end{array}$ & $\begin{array}{l}\text { (1) Special lecture "Sensor and network technology," "Trends in ubiquitous technology"; Research report } \\
\text { "Control development," "System development," "Construction and maintenance" } \\
\text { (2) Special lecture "PLC-OPEN activities and technical trends in PLC"; Research report }\end{array}$ \\
\hline $\begin{array}{l}\text { Plant } \\
\text { Engineering }\end{array}$ & $\begin{array}{l}\text { (1) Technical Subcommittee report "Serious accident prevention technologies and risk management"; } \\
\text { Presentation of case studies; Special technological lecture "Accident prevention technologies and } \\
\text { equipment control"; Technological lecture "Steel structure integrity diagnosis technologies," "Yard } \\
\text { machinery design outline and key points for maintenance," "Issues and recommendations for } \\
\text { popularization of machine safety management" } \\
\text { (2) Common subject "Hydraulic and lubrication technologies for extreme environments"; Special lecture } \\
\text { "Ideal state of tribology in severe atmospheres"; Technological lecture "Introduction to roll coolant } \\
\text { devices in recent cold rolling equipment"; Lecture by plant engineering company }\end{array}$ \\
\hline $\begin{array}{l}\text { Quality } \\
\text { Control }\end{array}$ & $\begin{array}{l}\text { (1) (Mechanical Testing Division) Regular work result report; Automation and labor-saving report; } \\
\text { Technical Subcommittee report; Information exchange sheet summary report, Periodical survey report on } \\
\text { actual conditions in mechanical testing; Special lecture "Trends in JIS and ISO standards for mechanical } \\
\text { testing" } \\
\text { (2) (QAQC Division) Common subject "Current status and issues in responsibility, authority, and } \\
\text { activities of quality assurance departments"; Special lecture "Concepts and methods for prevention of } \\
\text { human error" }\end{array}$ \\
\hline $\begin{array}{l}\text { Analysis } \\
\text { Technology }\end{array}$ & $\begin{array}{l}\text { (2) Technical Subcommittee report; Research Group/Forum report; Introduction of } \\
\text { standardization-related matters; Presentation by personnel engaged in frontline analysis work; Special } \\
\text { lecture "Research on high accuracy inorganic analysis methods using electrochemical techniques" }\end{array}$ \\
\hline
\end{tabular}


ISIJ International, Vol. 46 (2006), No. 7

Table 9. Research groups terminated in fiscal 2005.

\begin{tabular}{|c|c|c|c|c|c|}
\hline No. & Research Group & $\begin{array}{l}\text { Research } \\
\text { Period }\end{array}$ & Division & Group Leader & Purpose \\
\hline 1 & $\begin{array}{l}\text { Development of } \\
\text { New } \\
\text { Coke-making } \\
\text { Technology for } \\
\text { Non- or } \\
\text { Slightly-Caking } \\
\text { Coals }\end{array}$ & $\begin{array}{l}\text { April } 02 \text { to } \\
\text { March } 06\end{array}$ & $\begin{array}{c}\text { High- } \\
\text { Temperature } \\
\text { Processes }\end{array}$ & $\begin{array}{l}\text { Koichi Miura, } \\
\text { Kyoto Univ. }\end{array}$ & $\begin{array}{l}\text { Basic research to establish "Technology for coke } \\
\text { strength control in high rate use of low-grade coal" } \\
\text { which suppresses coke strength decrease, against the } \\
\text { declining supply of high quality coal (large increase } \\
\text { in non- or slightly-caking coals). }\end{array}$ \\
\hline 2 & $\begin{array}{l}\text { High- } \\
\text { Temperature } \\
\text { Property Vaues } \\
\text { of Fused Oxides }\end{array}$ & $\begin{array}{l}\text { April } 02 \text { to } \\
\text { March } 06\end{array}$ & $\begin{array}{c}\text { High- } \\
\text { Temperature } \\
\text { Processes }\end{array}$ & $\begin{array}{c}\text { Kazuhiro } \\
\text { Nagata, } \\
\text { Tokyo Institute } \\
\text { of Technology }\end{array}$ & $\begin{array}{l}\text { Survey and evaluation of important and recent data } \\
\text { for steelmaking on the high temperature physical } \\
\text { property values of viscosity, surface (interfacial) } \\
\text { tension, and heat conduction of fused slag, } \\
\text { development of estimation methods, measurement, } \\
\text { recording of measurement methods, and collection } \\
\text { of examples, and publication of the results thereof in } \\
\text { book form. }\end{array}$ \\
\hline 3 & $\begin{array}{l}\text { Control of } \\
\text { Physical } \\
\text { Limitation on } \\
\text { Blast Furnace } \\
\text { Operation for } \\
\text { Minimizing } \mathrm{CO}_{2} \\
\text { Gas Emission }\end{array}$ & $\begin{array}{l}\text { April } 02 \text { to } \\
\text { March } 06\end{array}$ & $\begin{array}{c}\text { High- } \\
\text { Temperature } \\
\text { Processes }\end{array}$ & $\begin{array}{c}\text { Masakata } \\
\text { Shimizu, } \\
\text { Kyushu Univ. }\end{array}$ & $\begin{array}{l}\text { Research for extraction of physical limitations and } \\
\text { their control on the blast furnace operation, } \\
\text { elimination of unstable phenomena in low fuel ratio } \\
\text { operation, and total improvement of the accuracy of } \\
\text { blast furnace model analysis, with the objective of } \\
\text { realizing low fuel operation in order to minimize } \\
\mathrm{CO}_{2} \text { gas emission. }\end{array}$ \\
\hline 4 & $\begin{array}{l}\text { Structural } \\
\text { Control of } \\
\text { Steels through } \\
\text { Phase } \\
\text { Transformatio } \\
\text { ns in a High } \\
\text { Magnetic Field }\end{array}$ & $\begin{array}{l}\text { April } 02 \text { to } \\
\text { March } 06\end{array}$ & $\begin{array}{l}\text { Microstructure } \\
\text { and Properties } \\
\text { of Materials }\end{array}$ & $\begin{array}{l}\text { Hideyuki } \\
\text { Ohtsuka, } \\
\text { National } \\
\text { Institute for } \\
\text { Materials } \\
\text { Science }\end{array}$ & $\begin{array}{l}\text { Elucidation of the basic principles of structural } \\
\text { control, including the transformation mechanism } \\
\text { responsible for texture orientation and the degree to } \\
\text { which texture control is possible with a magnetic } \\
\text { field, by clarifying the effects of a strong magnetic } \\
\text { field on the transformation behavior and structures } \\
\text { in various type of solid/solid phase transformations } \\
\text { in iron and steels. }\end{array}$ \\
\hline
\end{tabular}

Table 10. New research groups started in fiscal 2006.

\begin{tabular}{|c|c|c|c|c|}
\hline No & Research Group & Division & Group Leader & Outline \\
\hline 1 & $\begin{array}{l}\text { Development of } \\
\text { New Cokmeking } \\
\text { Technology for High } \\
\text { Strength and High } \\
\text { Reactivity Coke }\end{array}$ & $\begin{array}{c}\text { High } \\
\text { Temperature } \\
\text { Process }\end{array}$ & $\begin{array}{l}\text { Koichi Miura, } \\
\text { Kyoto Univ. }\end{array}$ & $\begin{array}{l}\text { Basic research for the establishment of "Technology for } \\
\text { production of high strength/high reactivity coke" which } \\
\text { enables a reduction in reducing agent use (coke ratio) in } \\
\text { order to develop a technology responding to deterioration } \\
\text { of the quality of coal resources and reduction of } \mathrm{CO}_{2} \\
\text { emissions in the ironmaking process. }\end{array}$ \\
\hline 2 & $\begin{array}{l}\text { Modeling for } \\
\text { Predicting } \\
\text { Microstructure and } \\
\text { Mechanical } \\
\text { Properties }\end{array}$ & $\begin{array}{l}\text { Microstructure } \\
\text { and Properties } \\
\text { of Materials / } \\
\text { Processing for } \\
\text { Quality } \\
\text { Products }\end{array}$ & $\begin{array}{c}\text { Takehide } \\
\text { Senuma, } \\
\text { Okayama } \\
\text { Univ. }\end{array}$ & $\begin{array}{l}\text { Improvement in the accuracy of modeling for } \\
\text { microstructure prediction and expansion of its range of } \\
\text { application, and construction of high accuracy material } \\
\text { composition equations which consider the microstructure } \\
\text { by multi-scale modeling, applying new methodologies } \\
\text { such as first-principles calculation, phase field method, } \\
\text { polycrystal plasticity theory, homogenization method, } \\
\text { etc., and dramatic improvement in forming simulation } \\
\text { accuracy by development of a micro-mechanical model } \\
\text { using the above. }\end{array}$ \\
\hline 3 & $\begin{array}{l}\text { Advancement of } \\
\text { Sensing } \\
\text { Technologies for } \\
\text { Plant Safety } \\
\text { Conditions }\end{array}$ & $\begin{array}{l}\text { Instruction, } \\
\text { Control and } \\
\text { System } \\
\text { Engineering }\end{array}$ & $\begin{array}{l}\text { Satoshi Honda, } \\
\text { Keio Univ. }\end{array}$ & $\begin{array}{l}\text { Development of advanced electromagnetic/ultrasound- } \\
\text { based sensing and signal processing technologies, etc. and } \\
\text { research on basic technologies enabling quantitative } \\
\text { measurement/evaluation of the safety of large-scale } \\
\text { equipment. }\end{array}$ \\
\hline 4 & $\begin{array}{l}\text { Development of } \\
\text { Environmentally } \\
\text { Friendly Steel } \\
\text { Analysis Techniques }\end{array}$ & $\begin{array}{c}\text { Process } \\
\text { Evaluation and } \\
\text { Material } \\
\text { Characterization }\end{array}$ & $\begin{array}{l}\text { Koichi Oguma, } \\
\text { Chiba Univ. }\end{array}$ & $\begin{array}{l}\text { Improvement in the reliability of quality control for iron } \\
\text { and steel products by development of rapid, high } \\
\text { sensitivity analytical methods for tramp elements, } \\
\text { responding to increasing use of scrap, in order to secure } \\
\text { production of high quality products. Objectives also } \\
\text { include contribution to environmental protection by the } \\
\text { development of zero emission analysis methods. }\end{array}$ \\
\hline 5 & $\begin{array}{l}\text { Effective Use of } \\
\text { Waste Heat in the } \\
\text { Steelmaking } \\
\text { Industry }\end{array}$ & $\begin{array}{l}\text { Environmental } \\
\text { and Energy } \\
\text { Technology }\end{array}$ & $\begin{array}{c}\text { Tomohiro } \\
\text { Akiyama, } \\
\text { Hokkaido } \\
\text { Univ. }\end{array}$ & $\begin{array}{l}\text { Development of phase change materials (PCM) with large } \\
\text { latent heat, mainly at } 200^{\circ} \mathrm{C} \text { or higher, which enable high } \\
\text { density storage and reuse at a fixed temperature for waste } \\
\text { heat of iron and steel, which is generated discontinuously } \\
\text { and had been difficult to recover, and investigation/study } \\
\text { of the possibility of application thereof. }\end{array}$ \\
\hline
\end{tabular}


content of their activities, and cooperation between industry and academia is promoted by establishing a correspondence with the Divisions in the Academic Society. Exchanges such as participation of university researchers in Committee Meetings and joint planning and mutual participation in operation with the Academic Divisions, which are promoted in order to strengthen cooperation between industry and academia, are continuing to take root.

On the other hand, the Technical Committees also maintained a high level in regular internal activities. As shown in Table 8 in FY2005, Committee Meetings were held to consider common/priority topics at the present point in time. As in the previous fiscal year, the Technical Society held a total of 35 Committee Meetings (Spring: 17, Autumn: 18). The total number of participants, at 2659 , showed a slight increase from the previous year (2581 in FY2004). The total number of university researchers participating in Committee Meetings also increased to 73 from 61 in FY2004. In particular, the Heavy Plate Committee held its 100th Meeting, for which it prepared a commemorative publication, "Current Status of Plate Manufacturing Equipment in Japan."

In FY2005, a total of 28 Technical Subcommittees, which carried out joint studies of designated technical topics on a priority basis, including 14 which were newly created during 2005, conducted activities and positively developed technology creation programs.

Introduction of a commendation system intended to improve the quality of published papers and educate young engineers is firmly established, and outstanding published papers are contributed to the ISIJ journal, Tetsu-to-Hagané.

\subsection{Interdisciplinary Technical Committees}

Among Interdisciplinary Technical Committees studying interdisciplinary and inter-industry technical problems, the Committee on Control of Second-phase Particles in Structural Steels for Improved Properties concluded its work in FY2005. The committee conducted discussions/investigations on techniques for controlling and utilizing "second-phase particles," such as precipitates and martensite-austenite constituents (M-A), which have large effects on the mechanical properties of the base material and weld- ed joints in practical structural steels. Establishment of a Committee on Microstructural Effects on Fracture Properties of Modern Structural Steels as a successor to the above-mentioned committee is planned for FY2006.

\subsection{Research Groups}

During FY2005, 24 research groups were active, and among these, 3 groups concluded their activities in March 2006. An outline of the terminated groups is shown in Table 9.

In FY2006, 5 new research groups (Table 10) will begin activities. Their research activities will encompass a wide range of fields from the upstream processes to downstream processes and peripheral technologies for iron and steel, including subjects such as effective utilization technologies for resources, computational technologies for predicting the microstructures and mechanical properties of iron and steel materials, equipment safety sensing technologies, environment-friendly iron and steel analysis technologies, and technologies for effective utilization of waste heat in iron and steel manufacturing processes. Promotion of active industry-academic cooperation is expected. Among these new groups, because the Research Group on Modeling for Predicting Microstructure Mechanical Properties was proposed by two divisions, the Division of Microstructure and Properties of Materials and the Division of Processing for Quality Products, attention will be focused on its future activities as a cooperative research group involving multiple Divisions of the Academic Society.

The ISIJ's academic support system was reviewed. As a result, beginning in FY2006, "Iron and Steel Research for Industry-initiated Project Development" will be started as a new group research system, and research groups will be classified into three types, intellectually-intensive type, technical development type, and search for new iron and steel-related fields type.

\section{Acknowledgement}

The author wishes to express his deep appreciation to the Japan Iron and Steel Federation and to all those concerned at the Iron and Steel Institute of Japan for their cooperation in all stages of the drafting of this paper. 


\section{论败 Production Technology Topics 论证}

"Production Technology Topics" present an outline of noteworthy achievements in technical development, new equipment, new products, etc. in 2005.

\section{Environment}

\section{Recovery and Recycle of Nickel from Sludge and Dust}

\section{Daido Steel Co., Ltd.}

Daido Steel has developed an innovative technology/

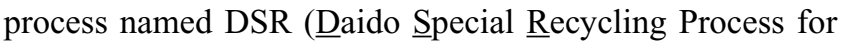
Direct and Smelting Reduction) which is capable of recovering Nickel from sludge and dust. In October 2005, the DSR started its operation at Chita Plant.

Generally, there are two problems:

- Ferro-Nickel generated by conventional process such as a resistance furnace or a rotary furnace cannot be utilized due to its low Nickel content.

- Sludge and dust in the steel manufacturing are dumped to reclaimed lands.

This new technology/process DSR has the following characteristics:

1. Preferential recovery of Nickel: Powdery wastes such as dry sludge and dust are injected into high temperature flame of the specially designed fuel-oxygen burner. In this DSR process, Nickel can be preferentially recovered from fused metal oxides. Nickel content of Ferro-Nickel can be increased several times as high as that of dry sludge and dust. This Ferro-Nickel is expected to be recycled as raw material for steelmaking.

2. Recycle of slag: Secondary slag can be recycled as road construction materials and the exhaust heat from combustion is utilized to dry sludge.

Development of this technology/process is supported by the fund of the Ministry of Economy, Trade and Industry and Aichi Prefecture as a part of the "Aichi Echo-town Plan" for its effective and advanced recycle business model. DSR is expected to promote recycling of wastes and to contribute to the establishment of recycling-oriented society.

\section{Blast Furnace and Slag}

\section{No. 5 Blast Furnace at West Japan Works (Fuku- yama) Blown In-Revamp Completed in 58 Days, World Record for Large BF-}

\section{JFE Steel Corporation}

JFE Steel Corporation blew in the newly revamped No. 5 blast furnace (BF) at the West Japan Works (Fukuyama) for its third campaign on March 31, 2005.

The revamp was carried out between February 1 and March 30 using the large-block ring construction method, JFE Steel's proprietary ultra-short-term revamping technology. The company has successfully used this method to shorten the revamping periods of BFs at its East Japan Works (Chiba) and West Japan Works (Kurashiki), but the latest revamp was the first time this method was employed at the Fukuyama district. It took only 58 days, a world record for a large $\left(5000 \mathrm{~m}^{3}\right.$ class $) \mathrm{BF}$, breaking the previous record of 62 days for the revamp of the No. $6 \mathrm{BF}$ at the Chiba district in 1998.

The comparison of the large block ring method and the conventional construction is shown in Table 1.

The Fukuyama No. 5 BF's inner volume has increased from 4664 to $5500 \mathrm{~m}^{3}$, and there are now four tapping holes instead of three. The furnace currently operates with four hot stoves as a previously out-of-service stove was renovated.

A new bell-less top has replaced a four-bell device in the furnace top raw material charging equipment, further improving raw material distribution control and enabling use of greater volumes of less costly raw materials, which results in lower production costs.

Main specifications comparison of revamp before and after is shown in Table 2.

In addition, highly corrosion resistant refractories were used and the shaft cooling system was reinforced among other measures to further prolong the operating life of the furnace.

Table 1. Comparison of the large block ring method and the conventional construction method.

\begin{tabular}{|c|c|c|}
\hline & Conventional & $\begin{array}{c}\text { Large-block ring } \\
\text { construction }\end{array}$ \\
\hline method & \\
\hline Units No. & $500 \sim 1,000$ & $3 \sim 4$ \\
\hline $\begin{array}{c}\text { Units } \\
\text { Weight }\end{array}$ & $10 \sim 20 \mathrm{t}$ & $\sim 2,000 \mathrm{t}$ \\
\hline $\begin{array}{c}\text { Revamp } \\
\text { duration }\end{array}$ & $\sim 130$ day & 58 day \\
\hline
\end{tabular}

Table 2. Main specifications comparison of revamp before and after.

\begin{tabular}{|c|c|c|}
\hline & 2nd campaign & 3rd campaign \\
\hline Inner volume & $4664 \mathrm{~m}^{3}$ & $5500 \mathrm{~m}^{3}$ \\
\hline Charging Device & four-bell top & 3 parallel bell-less top \\
\hline No. of tap holes & 3 & 4 \\
\hline
\end{tabular}

Water Retentive Material "Road Cool"-Using Ground Granulated Blast-furnace Slag for Heat Island Phenomenon Mitigating Pavement JFE Steel Corporation

JFE Steel Corporation developed water retentive material "Road Cool" for heat island phenomenon mitigating pavement and has placed it on the market in the summer of 2005.

"Road Cool" has the following distinctive features.

- Sustainability of road surface temperature reduction effect

"Road Cool" is designed for rapid and efficient absorb- 
ing of water, such as rain and sprinkled water, by optimizing raw materials. A cooling performance in a practical pavement with thickness of $10 \mathrm{~cm}$ and filling "Road Cool" in $75 \%$ of internal void space of asphalt pavement indicates that the temperature of the "Road Cool" pavement is approximately $15^{\circ} \mathrm{C}$ lower than that of dense graded asphalt pavement on the first day, and $6-8^{\circ} \mathrm{C}$ lower even after one week fine days in a row.

- Durability of water retentive performance

Some of water retentive materials in market show that cooling performance decline in use, because porosity of the materials gradually decreases depending on solidification of cement contained for hardening the materials. In contrast, "Road Cool" keeps its pore volume and size and also shows no other degradation during accelerated tests that indicated durability of 5 years or more has been confirmed. An experimental water retentive pavement using "Road Cool" was constructed on JFE Steel East Japan Works (Chiba) in March 2004, and it shows that cooling performance of the road temperature on 1 year after the construction was approximately same as that of soon after the construction.

- Environmental-friendly material

No leaching of harmful substances has been observed, confirming that "Road Cool" is an environmental-friendly material.

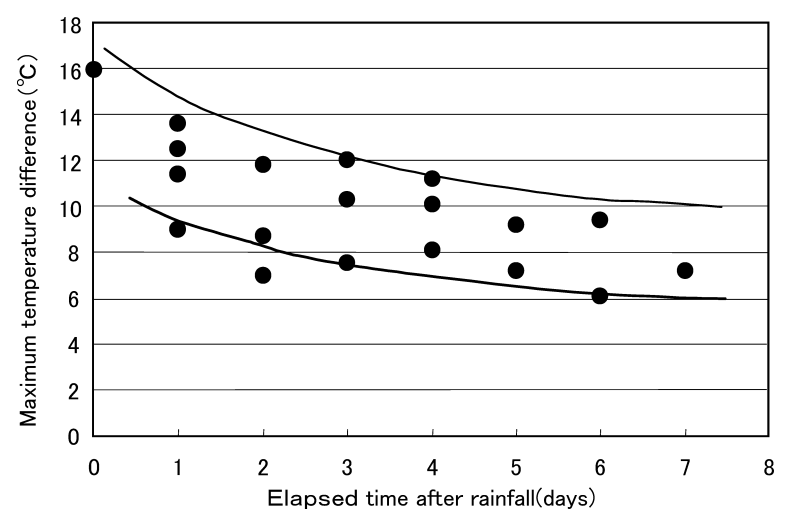

Fig. Sustainability of road surface temperature reduction effect.

\section{The Development of the Offshore Fertilizing Technology Using Steel Slag to Improve Seaweed Withering Conditions on Shoals \\ Nippon Steel Corporation}

With the objective of practical application of a mixture of steel-mill slag and other humic substances for improving seaweed withering conditions found on many foreshores around Japan, Nippon Steel has conducted a fertilizing test in a sea area in Mashike-machi, a town in Hokkaido.

Japan's coastal areas are threatened with the disappearance of communities of kelp, wakame - seaweed and other useful seaweeds, with rocks and rockbeds becoming covered rapidly with invading white calcareous algae (sea desertification). Fast disappearing habitats and spawning grounds of fish and shellfish are also beginning to affect coastal fishery. It is urgent, therefore, to try to accelerate the regeneration of the fertile ecosystem of the sea. Seawater warming, water pollution and other environmental changes, sea urchins eating away at useful algae and also many other factors lead to such desertification of the sea.
One such conceivably contributing factor is the dwindling supply of divalent iron ion, which, although essential for the growth of useful algae, has been decreasing because reckless deforestation taking place upstream of the rivers flowing into the sea has lessened the natural production of humic acid iron in humus.

Professor Sadakata of Kogakuin University (Professor Emeritus of the University of Tokyo) and others have researched improving seaweeds-withering conditions at the University of Tokyo, for many years. On a laboratory scale, they have established that humic acid iron present in a mixture of steel-mill slag and other such divalent-iron-ion-containing substances and humic substances from fermentation of waste wood chips is effective in accelerating the growth of algae.

In order to ascertain the effect of the above findings, Nippon Steel, jointly with Eco.Green.Co., Ltd. and Nishimatsu Construction Co., and with the cooperation of the Fishery Cooperative Association of Mashike-machi, Hokkaido, installed a fertilizing unit, about $15 \mathrm{~m}$ wide, composed of a mixture of steel-mill slag and humic substances on shoals (on the landside of the foreshore) on the Shaguma beach of the township, in November 2004. Submarine observation conducted since March 2005 has confirmed that on a seabed previously covered entirely with white calcareous algae and the like for several years, kelp and other seaweeds have grown abundantly over an area extending about $30 \mathrm{~m}$ offshore from the unit installation site. This result is believed to be the first time that the effectiveness of a mixture of divalent-iron-ion-containing substances and humic substances in reducing sea desertification has been ascertained.

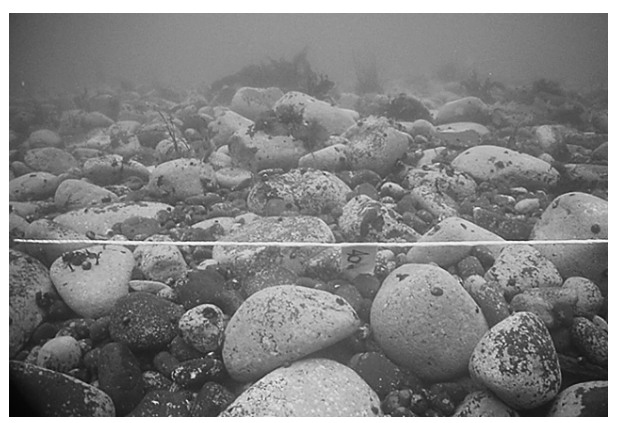

Fig. 1. The situation before the fertilizing-unit installation.

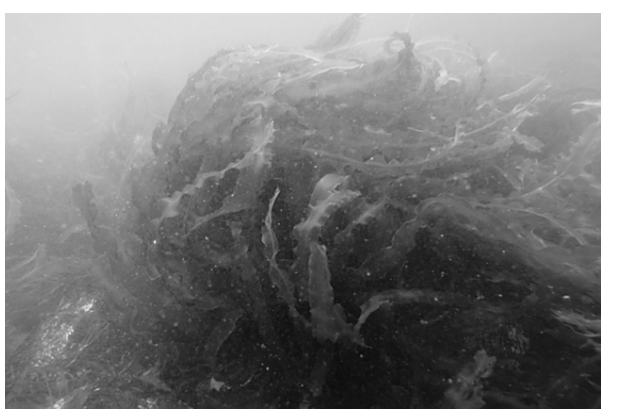

Fig. 2. The situation after.

By courtesy of Shibuya Diving Industry Co., Ltd. 


\section{Converter and Electric Arc Furnace}

\section{Energy-saving Process/Operation on "New Electric Furnace with Direct Linkage-type Scrap Preheating Shaft}

\section{JFE Bars \& Shapes Corporation}

New EAF with direct linkage-type scrap preheating shaft has been on operation smoothly on our Himeji works, JFE Bars \& Shapes corporation from November 2005.

We replaced our conventional $150 \mathrm{t}-\mathrm{EAF}$ to new type EAF, and this is the 1st practice on such large volume EAF.

There are two main process on making steel products, one is steel-making process which makes billet from melting scraps, and one is rolling-process which makes consumer shapes/bars etc. from billets.

Usually on EAF-using process, $80 \%$ of total energy consumption for getting final products from scraps is on scrapmelting process on EAF.

The conventional EAF has the drawback of excessive heat loss $(43 \%)$ due to opening of the furnace roof for scrap charging and discharge of high temperature exhaust gas during operation.

In contrast in the revamped furnace, the scrap preheating shaft is connected directly to the melting chamber enabling heat recovery.

Featuring virtually continuous scrap charging from the shaft top, heat loss will be reduce by large $14 \%$, realizing an important energy saving. This technology was adopted by NEDO (New Energy and Industrial Technology Development Organization) as a support Project for Industries for increasing the Efficient Use of Energy for FY2004

Due to its closed furnace structure, this is also a clean technology with minimum leakage of off-gas, and its therefore expected to be useful in using Automobile press scrap under the End-of- life Vehicles (ELVs) recycling law.

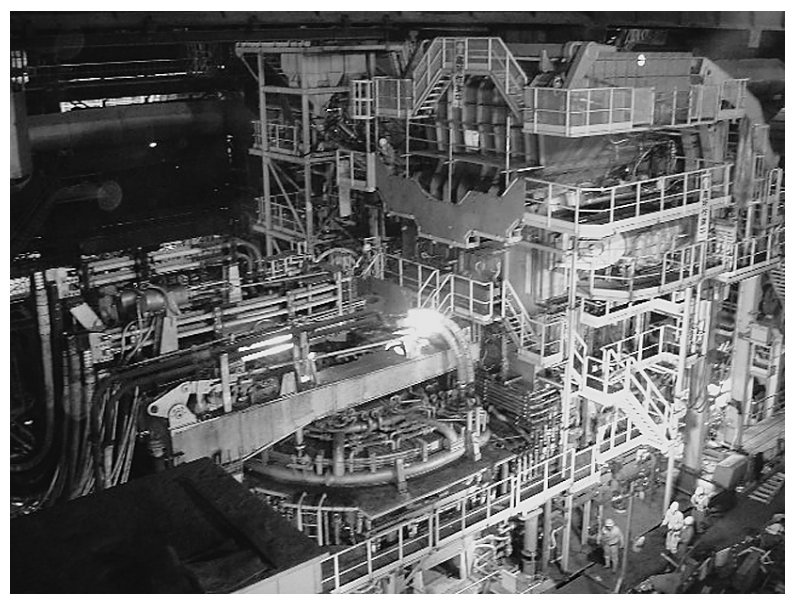

Fig. New type EAF.

\section{Energy Saving by Development of High Efficient Process in Steelmaking Sumitomo Metal Industries, Ltd. and Sumikin Iron and Steel Corporation}

Sumitomo Metal Industries and Sumikin Iron and Steel Corporation developed the high efficient steelmaking process in Wakayama Steel Works in 2005. It is the highlight of the high efficient steelmaking process that the hot metal dephosphorization treatment by utilizing the specific top and bottom blowing BOF was adopted for every steel grade in order to achieve a simple process and realize the high productivity steelmaking shop. Consequently, the energy saving was achieved, and the amount of energy saving is estimated to about $340000 \mathrm{t} \mathrm{CO}_{2}$ emission reduction per year.

The steelmaking shop in Wakayama Steel Works has produced various kinds of steel grades in order to meet the needs of various customers' products, such as exposed steel for automobiles, electrical steel sheet, oil country tubular products, tubes for nuclear power plant, wheels and axles etc. Due to such product mix, the steelmaking process flow was very complicated since the refining process was different for each steel grade. Therefore, the improvement of process was indispensable.

The steelmaking shop with high productivity, which met the requirement for high quality steel, such as low phosphorus content steel and could produce them, was built in 1999, and started its operation. Then, the various developments for the high efficient process have been performed at the new steelmaking shop.

Four technologies that realized the high efficient operation are listed below.

1. The first development of the hot metal dephosphorization treatment by utilizing the specific top and bottom blowing BOF in the world.

2. The highest-speed decarburization blowing in the world, which made it possible to achieve 9 min blowing and 20 min of Tap-Tap.

3. The first adoption of special layout of the deposphorization and decarburization furnaces in the world in order to realize the one way direction material flow to avoid the crane interference in the steelmaking shop.

4. The long life of 20000 heats in dephosphorization furnace and the short period furnace relining of $5.5 \mathrm{~d}$ in order to achieve the high utilization ratio of deposphorization and decarburization furnaces.

As mentioned above, the high efficient steelmaking process brought the energy saving due to heat loss reduction, decrease of energy consumption and the decrease of lime consumption. The energy saving which was estimated to about $340000 \mathrm{t} \mathrm{CO}_{2}$ emission reduction per year was achieved. Furthermore, the separation and recovery of zinc content dust and the reduction of slag amount realized the

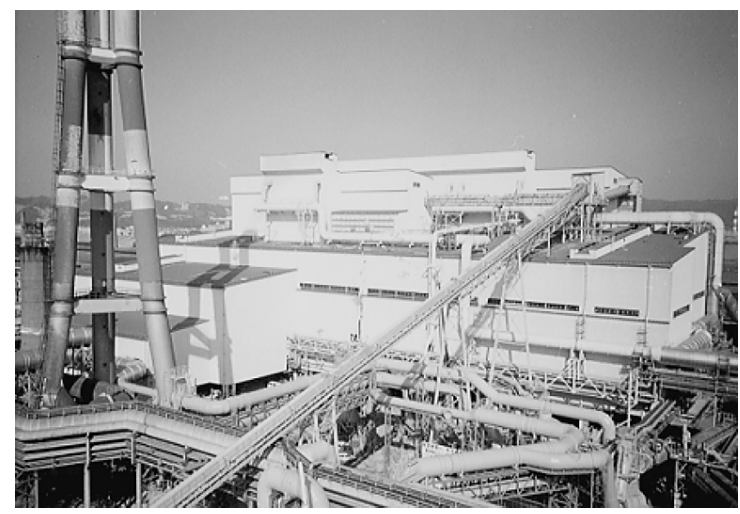

Fig. View of the steelmaking shop in Wakayama Steel Works. 
environmental improvement as well. The high quality steel such as the low phosphorous, ultra low sulfur and low oxygen content steel has been produced stably with this process. The response to customers' requirement for both quality and delivery time has been improved. These developments surely and greatly contribute to the society.

\section{Hot Strip and Plate}

\section{Hot Rolled High Carbon Steel with Excellent Formability; "Hyper Burring SC"}

\section{JFE Steel Corporation}

JFE Steel Corp. developed hot rolled high carbon steel with excellent formability, "Hyper Burring SC". Hyper Burring SC has been applied to automatic transmissions parts such as clutch drum, which were difficult to form by press forming from sheet before. Although high carbon steel such as S35C or S45C has been already used in the disk shape parts of automatic transmissions, most of the parts are cast, forged and/or shaved because of poor formability of the material.

Hyper Burring SC has fine and homogeneous microstructure consisting of ferrite and spheroidized cementite after annealing. The microstructure can be realized by using super rapid cooling system "Super-OLAC H" which was awarded Okochi memorial engineering award in 2003. As a result of the fine microstructure, Hyper Burring SC has following characteristics.

(1) Elongation and hole expansionability are so much improved that press forming, including sheet forging, can be applicable even for complex shape parts.

(2) Properties of fine blanking and quench hardening are also improved.

(3) The part without hardening treatment also shows high strength and durability since the tensile strength of base material is more than $440 \mathrm{MPa}$.

Hyper Burring SC makes it possible to integrate and reduce the automatic transmissions parts that were separately formed and followed by welding. It is clear that the material can contribute to the improvement of performance and durability in automatic transmissions, and to the rationalization of manufacturing process in automotive industries

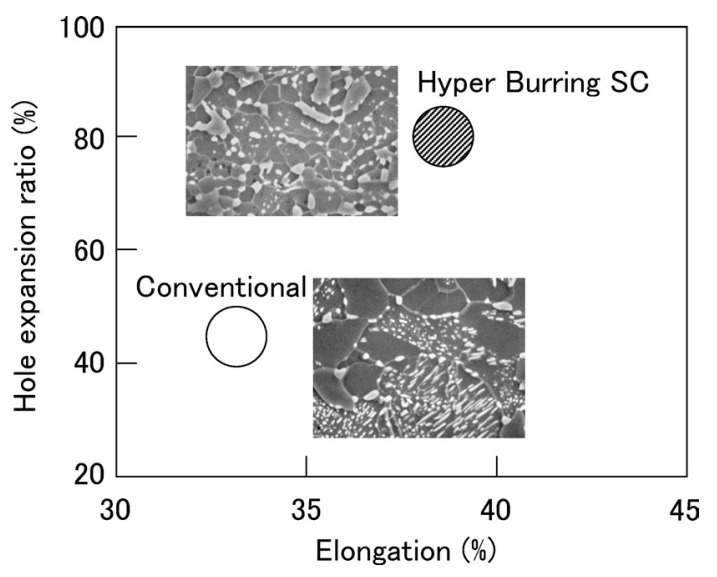

Fig. Mechanical properties of Hyper Burring SC and conventional steel in S35C

\section{First Application of SUMITEN610F-TMCP Steel Plates to Hydraulic Pipes for One of the Largest Power Plant in China}

Sumitomo Metal Industries, Ltd.

Sumitomo Metal Industries, Ltd. won the order of steel plates for the Long Tan Dam Project after for Three Gorges Dam. The dam will house a power plant with the second largest generating capacity of any facility in China when it is completed. The order comprises the entire amount of $610 \mathrm{~N} / \mathrm{mm}^{2}$ class high tensile strength heavy-gauge steel plates for hydraulic pipes. Hydraulic pipes funnel water onto the blades of the generating turbines that are the heart of hydroelectric power generation. Heavy-gauge steel plates used for hydraulic pipes require a high degree of strength, toughness and weldability due to high humidity in a tunnel.

Sumitomo Metal Industries, Ltd. has won a high reputation for its original technique on Thermo-Mechanical Control Process (TMCP), named Aus-Formed Bainite, ${ }^{1)}$ and has supplied this TMCP type of $610 \mathrm{~N} / \mathrm{mm}^{2}$ class high tensile strength heavy-gauge steel plates (brand name: SUMITEN610, equivalent to JIS G3115 SPV490) for hydraulic pipes for the first time in China.

The Long Tan Dam hydroelectric power plant is under construction in Tian'e County Guangxi Zhuang Autonomous Region of China. Its generating capacity will be $5400 \mathrm{MW}$, which is about four times of ones of Japan's largest Kurobe Dam hydroelectric power plant. Total amount of plates for hydraulic pipes is 4000 ton and Sumitomo Metal Industries, Ltd. has supplied $52 \mathrm{~mm}$ thickness plates of 3000 ton for bottom part, to which higher water pressure should be applied.

By taking this chance, Sumitomo Metal Industries, Ltd. is going to supply more amount of SUMITEN610-TMCP to hydroelectric power application, which is considered as

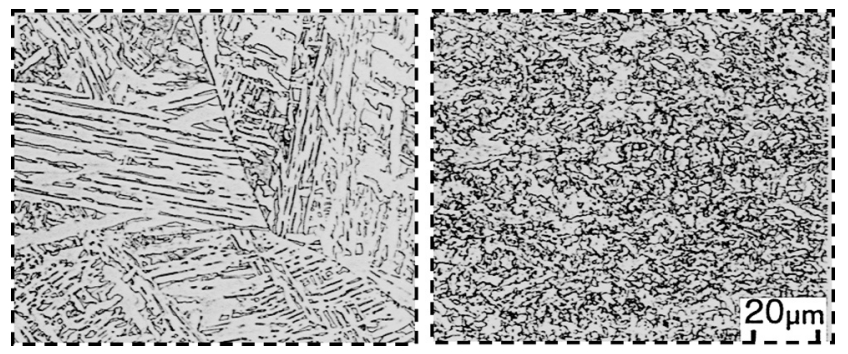

Fig. 1. Comparison of typical microstructure between of conventional QT (left) and of Aus-Formed Bainite (right).

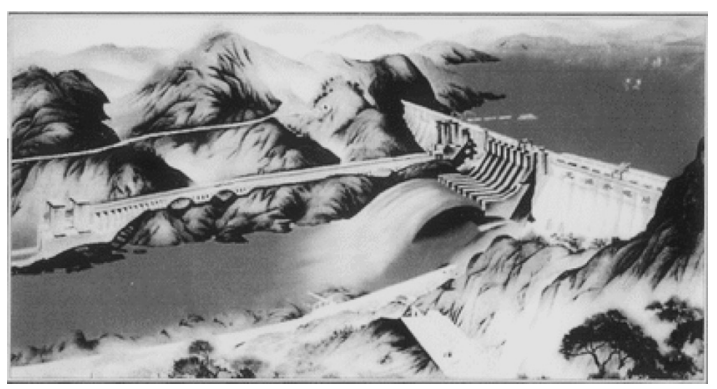

Fig. 2. Schematic of Long Tan Dam hydroelectric power. 
clean energy field. This product does not require preheating, which must normally be applied in welding, simplifying welding work and leading to substantial savings in the client's construction costs.

Note 1): JIM Technical Development Award, The Ichimura Prizes in Industry Contribution Prize, and so on are awarded.

\section{Development of Corrosion Resistant Steel for

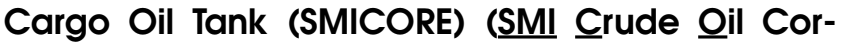 rosion Resistant $\underline{\text { Steel) }}$}

Sumitomo Metal Industries, Ltd.

Sumitomo Metal has newly developed the corrosion resistant steel, SMICORE for cargo oil tank in corrosion environments of both upper deck plate and bottom plate and put it to practical use.

From the viewpoint of the improvement of safety of ships and the prevention of sea pollution, the corrosion problem in the cargo oil tank has been closed up. Corrosion environment in the cargo oil tank is consisted of inert gas to prevent from exploding, $\mathrm{H}_{2} \mathrm{~S}$ originated from crude oil, $\mathrm{Cl}^{-}$ and $\mathrm{H}_{2} \mathrm{O}$. And there are two types of corrosion in the cargo oil tank, the general corrosion with flaky corrosion products in the vapor space of upper deck plate and the pitting corrosion at bottom plate.

Sumitomo Metal has established original test methods that can simulate the corrosion environments in cargo oil tank, at both upper deck plate and bottom plate, on basis of the corrosion mechanism studied by Japan shipbuilding research association (SR242). And the anti-corrosion material was developed through the investigation on the effects of alloying elements on corrosion behavior of steels in both enviroments, and the trail application began with several ships. The developed steel has mechanical properties, weld-

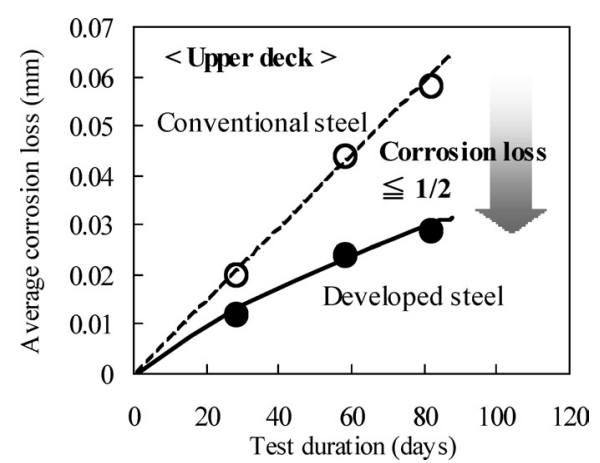

Fig. 1. Corrosion resistance of developed steel (upper deck).

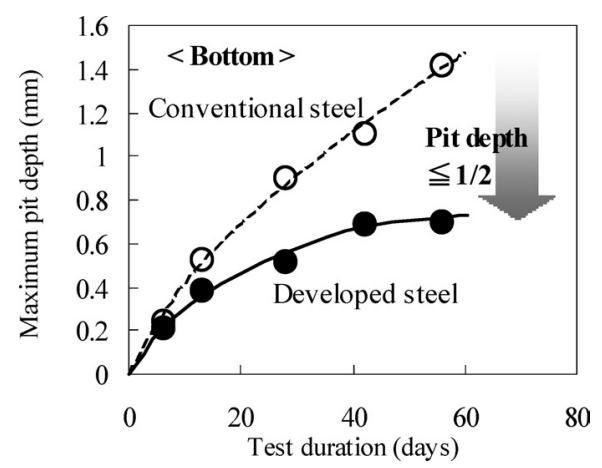

Fig. 2. Corrosion resistance of developed steel (bottom).

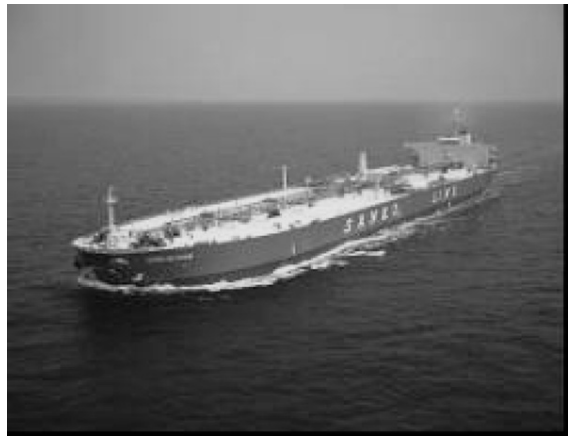

Fig. 3. The first SMICORE application trial ship "SANKO BLOSSOM". (Built by Sumitomo Heavy Industries Marine \& Engineering Co., Ltd., and bare-boat chartered by The Sanko Steamship Co., Ltd.)

ability, and welded joint properties equivalent to those of the conventional steel plates.

The developed steel was certificated from classification LR, NK, ABS, DNV as a hull structural steel. Especially LR approved that "The approved steel has twice or more corrosion resistance compared with conventional steel".

\section{Bar Steel and Wire Rod}

\section{Development of High Corrosion Resistance and High Strength Stainless Steel}

Daido Steel Co., Ltd.

Daido Steel has developed high strength stainless steel with superior corrosion resistance. Normally, high hardness stainless steel such as SUS440C is applied for parts which require corrosion resistance and wear resistance.

Generally, Chromium is added to stainless steel to improve corrosion resistance. However, since the high Chromium content decreases hardness after heat treatment (quenching and tempering), Chromium content is limited. Thus, corrosion of conventional high hardness stainless steel at chloride and/or seawater corrosive environment is inevitable.

Nitrogen is the element to improve corrosion resistance as well as Chromium. Therefore, various Nitrogen-added stainless grades have been developed. However, by the conventional steelmaking process, the maximum Nitrogen content is up to $0.1 \%$ due to the solubility limit of steel.

Daido Steel has developed pressurized and inert atmospheric induction melting and casting process, supported by the fund of New Energy and Industrial Technology Development Organization (NEDO). With this process, high Nitrogen stainless steel which contains more than $0.6 \%$ of Nitrogen can be manufactured.

This high Nitrogen stainless steel has the following characteristics:

- Hardness equivalent to high strength stainless steel such as SUS440C (HRC60)

- Corrosion resistance equivalent to seawater resistant steel such as SUS316

Thanks to these superior properties, the high Nitrogen stainless steel is expected to be widely applied to high strength and corrosion resistant parts such as bearing, pressure/flow control valve, cutting tool and dies in manufactur- 
ing industry: automobile, chemical plant, marine structure and IT etc.

\section{Development of an Air Hardened Microalloy Forging Steel for Fracture Splitting Connecting Rods}

Sumitomo Metals (Kokura), Ltd.

Sumitomo Metals (Kokura), Ltd., in collaboration with Honda Motor Co., Ltd., have developed and introduced an air hardened microalloy forging steel for fracture splitting connecting rods.

Conventional fracture splitting connecting rods, which are produced from sintered material or high carbon steel, have poor performance in fatigue strength and machinability. Sumitomo Metals (Kokura), Ltd. and Honda Motor Co., Ltd. have developed a new material and succeeded in solving these problems.

Connecting rods produced from the newly-developed material have been applied on new Honda automobiles.

Characteristics of the newly-developed material are:

(1) A special element has been added for precipitation hardening in order to obtain fracture splitting ability.

(2) The targeted high fatigue strength has been achieved by maintaining the Carbon content at an appropriate level and the above precipitation hardening.

(3) Lead, which improves machinability but is not environmentally friendly, has not been added.

(4) The fatigue strength of the newly-developed fracture splitting connecting rods has been enhanced by $30 \%$ compared to the traditional rods. In addition, the new rods are $13 \%$ lighter than conventional rods.

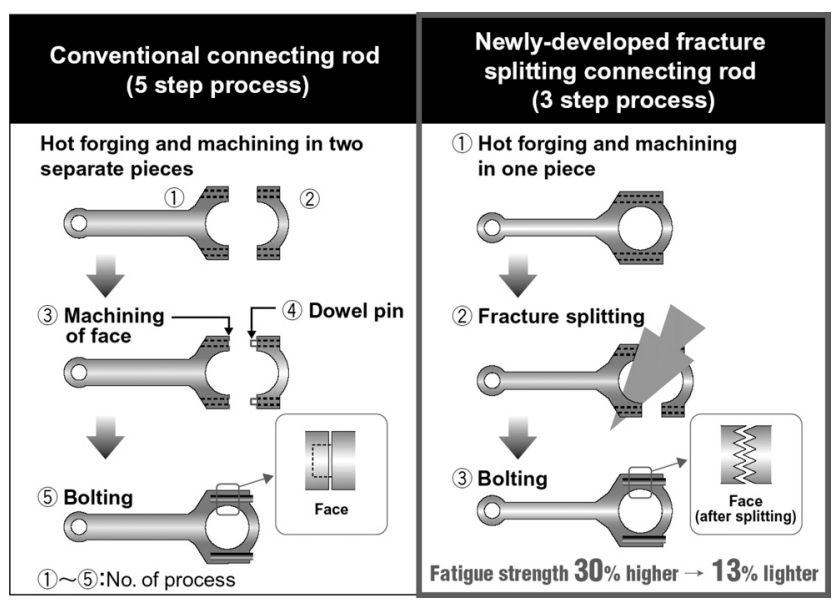

Fig. Conventional connecting rod (left) and newly-developed fracture splitting connecting rod (right).

\section{Pure Iron Type Soft Magnetic Materials, "ELCH2/ELCH2S"}

Kobe Steel Ltd.

Kobe Steel has developed pure iron type soft magnetic materials, ECLH2 series, which improve the performance and save electric power dissipation of electromagnetic parts for automobiles and contribute to the reduction of manufacturing costs for the parts.

Recently, reducing environmental pollution and saving energy have been the critical challenges, especially in the field of automobiles. From this point of view, a more precise and efficient control driving system is the most desirable. In the parts using electromagnetic force, like the solenoid and the actuator, iron core materials are used not only for coils to enhance a magnetic field but also for other uses to improve the response and the energy efficiency of the system. The low carbon steels (about $0.1 \% \mathrm{C}$ ) have conventionally been used as the iron core material for the general electromagnetic parts. However, with the remarkable progress in electromagnetic parts, further improvement in performance and power saving are becoming essential for these parts.

To meet these requirements, Kobe Steel has established a technology to reduce magnetic impurities and precipitates and to make them harmless. As a result, we have succeeded in commercialization of a pure iron type soft magnetic material ELCH2 having excellent magnetic property and cold forgeability.

Furthermore, for electromagnetic parts subjected to machining process, another pure iron type soft magnetic material $\mathrm{ELCH} 2 \mathrm{~S}$ has been developed and commercialized. In this material, machinability was improved by dispersing elements other than lead under optimal conditions utilizing the favorite technical know-how of Kobe Steel for special steel manufacturing.

Figure 1 shows the magnetic property of the ELCH2 series. The ELCH2 series have outstanding magnetic property superior to JIS SUY-1 grade. In addition, the excellent cold forgeability, the feature of the developed materials, can be utilized for "eliminating of heat treatment process" and "integrated forging for complicated shape". These properties will contribute remarkably to the improvement in performance and the reduction of manufacturing costs of various types of electromagnetic parts.

Both developed materials are being used for new automobile parts such as electromagnetic clutches and will be used more widely in the future.

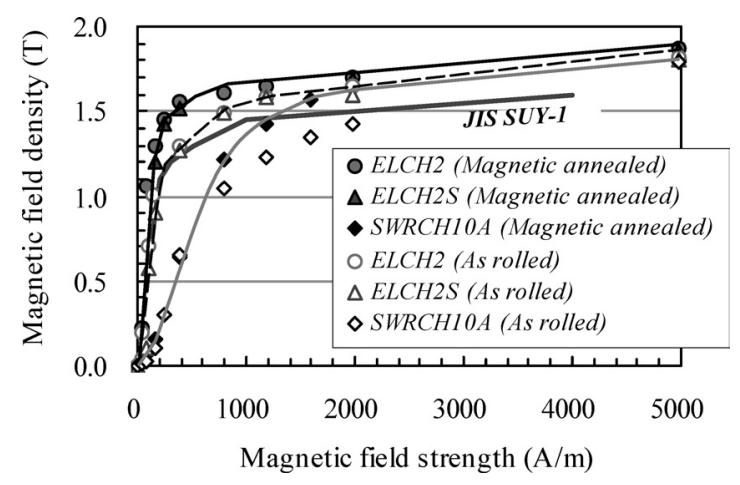

Fig. Magnetic field dependence of magnetic flux density.

\section{Stainless Steel}

\section{JFE443CT, a Ni, Mo-free Stainless Steel with High Corrosion Resistance}

JFE Steel Corporation

In recent years, the prices of raw materials such as iron ore and petroleum have risen rapidly, and such soaring of prices is becoming a serious concern. The price of SUS304, 
a major stainless steel, has been strongly influenced by the fluctuation of the nickel ore price. Besides, Cr-type stainless steels (without Ni addition) such as SUS436L (18\%Cr$1.2 \% \mathrm{Mo}$ ) are well known for its superior corrosion resistance, and have been widely used as a substitute material for SUS304. However, the price of molybdenum rose steeply, and Mo-containing Cr-type stainless steel with high corrosion resistance became expensive, i.e., less cost-competitive as a substitute material for SUS304.

To solve such situation, JFE Steel Corporation launched a Ni, Mo-free stainless steel with high corrosion resistance, JFE443CT. With the increase in the $\mathrm{Cr}$ content to $21 \%$, the newly-developed steel exhibits equivalent corrosion resistance to that of SUS304 without the addition of $\mathrm{Ni}$ and/or Mo, which means that the product is available at more stable price than the stainless steel including $\mathrm{Ni}$ and/or Mo. It is often said that mass production of high-Cr stainless steel is difficult. Nevertheless, the commercial production of this new steel, not as a specialized product but as a versatile product, has become possible, by utilizing the large volume vacuum oxygen decarburization (VOD) furnace for removing impurities such as carbon and nitrogen, and by making the most of JFE's vast experience in production of a variety of high-Cr stainless steel such as SUS447J1 $(30 \% \mathrm{Cr}-$ $2 \% \mathrm{Mo}$ ).

The main features of this steel are as follows:

(1) The corrosion resistance of JFE443CT is equivalent to that of SUS304.

(2) Since Ni and Mo are not added in JFE443CT, the cost of JFE443CT is competitive and stable compared to that of SUS304.

(3) Press formability of JFE443CT is equivalent to that of SUS436L, and is superior to that of SUS430 (16\% $\mathrm{Cr}$ ), the major grade of Cr-type stainless steel. In particular, the drawing formability of JFE443CT is superior to that of SUS304.

It is highly expected that, as a substitute stainless steel for SUS304, JFE443CT becomes a versatile material which will be widely applied to kitchen instruments, cutlery, household electrical appliances, interior/exterior parts of buildings, automotive exhaust system parts, reefer containers for maritime transport, and other uses.

\section{Testing and Analysis}

\section{Development of Accelerated Corrosion Test for Electrical Appliances: "ACTE"}

JFE Steel Corporation

Under the EU's RoHS Directive (RoHS: Restriction of the use of certain Hazardous Substances in electrical and electronic equipment), which took effect in February 2003, it will no longer be possible to use six designated substances (hexavalent chromium $(\mathrm{Cr}(\mathrm{VI}))$, etc.) in products after July 2006. In order to reduce hazardous substances in electrical appliances, the chromate coating used in zinccoated steel sheets is being changed to a chromate-free coating. The conventional accelerated corrosion tests, which are the salt spray test (SST) and the combined cyclic corrosion test (CCT), have been widely used in evaluating the corrosion resistance of zinc-coated steel sheets for elec- trical appliances. However, the correlation between these tests and the actual corrosion behavior of electrical appliances had not necessarily been clarified. In order to appropriately evaluate the corrosion resistance of zinc-coated steel sheets with the chromate-free coatings put into practical use recently, an appropriate corrosion test method based on the actual environment is necessary. Therefore, JFE Steel Corporation and Hitachi, Ltd. (Hitachi Research Laboratory) jointly developed the world's first accelerated corrosion test for zinc-coated steel sheets used in electrical appliances, "ACTE" (ACTE: Accelerated Corrosion Test for Electrical appliances, announced in 2003) as a replacement for the conventional accelerated corrosion tests (SST, CCT).

We disclosed the ACTE test conditions in 2005 and are encouraging adoption in the electrical appliance industry by use in making accurate evaluations of the corrosion resistance of zinc-coated steel sheets with the chromate-free coatings which are now increasingly applied to electrical appliances. The ACTE consists of a salt deposition process and a cyclic wet/dry process. As distinctive features of the ACTE, the test conditions simulate actual environments (use of artificial seawater, constant absolute humidity) and it is possible to estimate the corrosion life of materials in a wide range of use environments by obtaining dependency data on the main corrosion factors (amount of deposited sea salt, etc.) by varying the test conditions. Moreover, the applicability of the ACTE is not limited to electrical appliances, as it has been confirmed that ACTE test results show a good correlation with the results of atmospheric exposure tests of various types of zinc-coated steel sheets used in construction.

The start of a domestic project aimed at standardization of the ACTE method in the ISO as an atmospheric corrosion test method for coated materials and corrosion-resistant materials in ISO TC/156 (Corrosion of metals and alloys) is scheduled for 2006 .

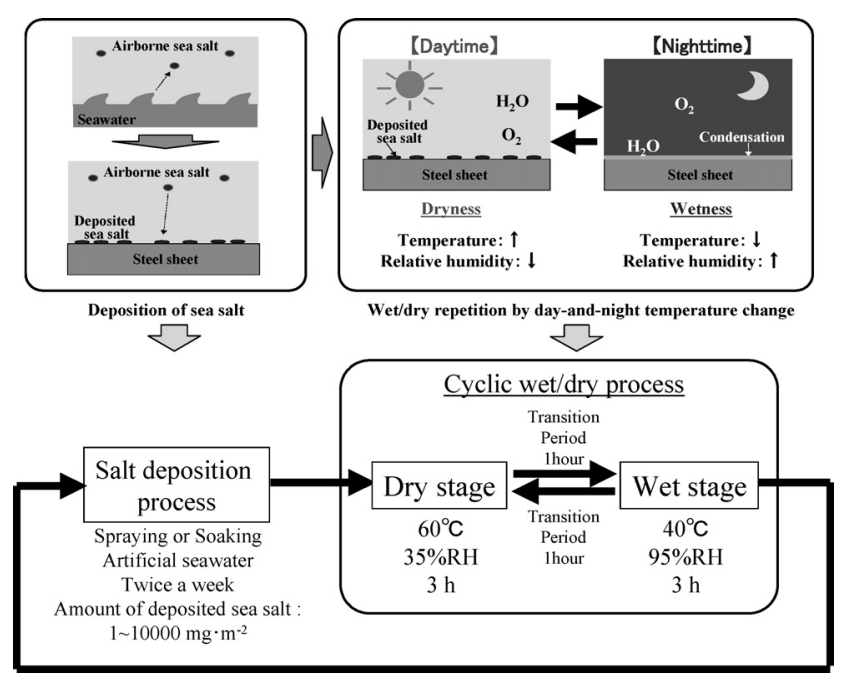

Fig. Typical test condition of new accelerated corrosion test "ACTE".

\section{Development of the Automatic Pretreatment System for Metallic-elements Measurement DKK-TOA CORPORATION}

DKK-TOA CORPORATION developed and put in practical use the "automatic pretreatment system for metallic- 
elements measurement" which automated required pretreatment operation in metallic-elements measurement $(\mathrm{Cd}, \mathrm{Cr}$, $\mathrm{Ni}, \mathrm{Pb}$, etc.). This equipment automates the method specified to the factory effluent examination method (JISK0102). The amount of the sample and reagent which are used with this equipment was reduced in the half of regulation of JIS.

This equipment automates a series of complicated processes of sample measurement, reagent addition, heating decomposition, cooling, filtration, decomposition liquid measurement, and washing. A recovery rate is $90 \%$ or more, $\mathrm{CV}$ is $5 \%$ or less. By development of this equipment, the stable processing was attained with less variation compared with operation of people.

The main features are as follows:

(1) The processing time per one sample are about 30$40 \mathrm{~min}$. Two kinds of processing processes based on JIS are equipped.

(2) The turntable which can set 36 samples at once, is available for an addition. Cancellation, and interruption are possible during processing.

(3) The heating decomposition cell which vapor-deposited on the outside of a silica glass cell is used, and it improves decomposition efficiency.

(4) Abundant alarm functions are equipped and oeration at night is possible.

Practical use is already presented with this machine, it is estimated that this equipment is equivalent performance to a skillful worker. We think that it can contribute to automa-

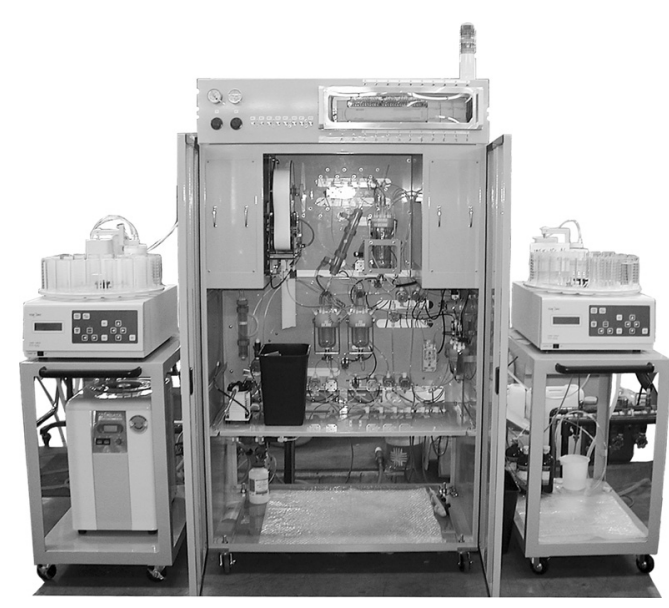

Fig. Automatic Pretreatment System. tion and laborsaving of a pretreatment in the analysis work spot in the near future.

\section{Earthquake-proof}

\section{The Development of a Revolutionary Earthquake- proof Technology Using Unbonded Brace Nippon Steel Corporation}

In conventional building construction, preventing loss to life and building collapse are the main aims of earthquakeresistant design, in which plasticization, residual deformation and other damage to buildings are accepted. However, a major earthquake occurring directly under the metropolis would most likely cause building damage amounting to several ten trillion yen, a prediction that calls for buildings having high resistance to seismic forces. Nippon Steel has developed the "UNBONDED BRACE" using special steel and, by its incorporation in a building structure, made it possible to reduce damage to a building and permit its continued use through absorption of seismic energy and easing of the shaking of the building.

This technology consists of the following three elements:

(1) Steels developed for outstanding absorption of seismic energy, having lower and more stable yield strength than conventional steels and excellent fatigue characteristics in the plastic region.

(2) "UNBONDED BRACE," a special quake-resistant member, developed to enable the steel (1) to give full performance as a member and stable performance in seismic-energy absorption.

(3) The new earthquake-resistant design method by which UNBONDED BRACE (2) is incorporated in a building structure to absorb seismic energy and reduce the shaking of the building, thereby restraining damage to columns and beams, and its practical application.

This development has thus made possible the reduction of damage and continued use of buildings. At present, the idea of reducing earthquake damage by the use of seismicenergy absorbing members has been adopted for most highrise steel-framed buildings in Japan. Moreover, through the disclosure of this technology and the supply of UNBONDED BRACE to the U.S., Taiwan, China and elsewhere, Nippon Steel has been contributing to the advance and spread of aseismic technology on a global scale.
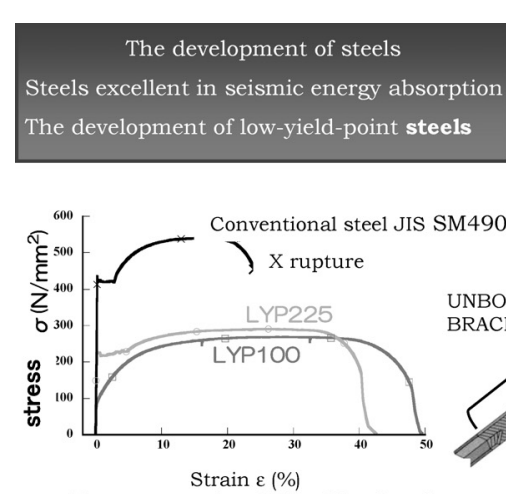

The stress-strain relationship of steels
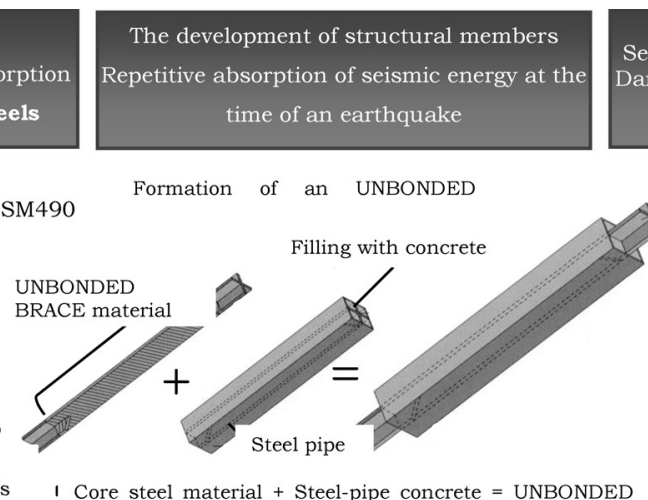

Fig. Outline of UNBONDED BRACE.
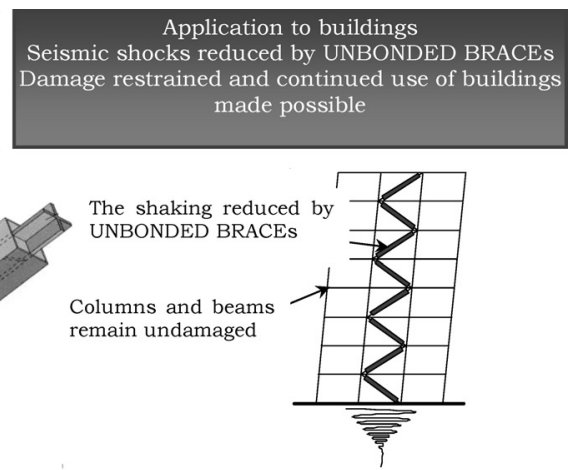